
A $\mathrm{C}$ T $\cdot \mathrm{A}$
T H E R I O L
$\mathrm{O} \quad \mathrm{G} \quad \mathrm{I} \quad \mathrm{C} \quad \mathrm{A}$
VOL. VII, 12.
BIAEOWIEŻA
10.XII.1963

Irena D Z I ER Z Y KR A Y - R O G A L S K A *

\title{
The Comection Between the Endocrine Activity oi the Parotid Salivary Glands and Parathyroid on the Basis of Morphological Pictures
}

Powiązanie czynności dokrewnej ślinianek przyusznych i przytarczycy na podstawie obrazów moriologicznych

[With 32 Figs. \& 4 Tables]

I. Introduction

II. Review of literature .

III. Material, methods and technique . . . . . . . . . . . . 222

IV. Effect of the removal of the parathyroid glands on the morphological picture of the salivary glands of the white rat . . . . . . 223

1. Operation technique . . . . . . . . . . . 223

2. Description of material . . . . . . . . . . . . . 224

3. Results . . . . . . . . . . . . . . . . . 226

V. Effect of removal of the parotid salivary glands on the morphological picture of the parathyroid glands . . . . . . . . . 226

1. Operation technique . . . . . . . . . . . . . . 226

2. Description of material . . . . . . . . . . . . . . 227

3. Results . . . . . . . . . . . . . . . 229

VI. Effect of administering parotin on the morphological picture of the parathyroid glands and the parotid salivary glands . . . . . 230

A. Parathyroid glands
1. Description of material . . . 231

2. Results . . . . . . . . . . . . . 231

B. Parotid salivary glands

1. Description of material . . . . . . . . . . 231

2. Results . . . . . . . . . . . . . . 232

VII. Effect of removal of the salivary glands and administering parotin on the autoradiographic picture of the bones of white rats . . . . 232

1. Description of material . . . . . . . . . . 233

2. Results . . . . . . . . . . . . . . 234

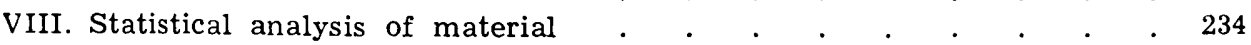

IX. Consideration of results and discussion . . . . . . . . . . . . 242

$\mathrm{X}$. Summary . . . . . . . . . . . . . . . . . . 247

References . . . . . . . . . . . . . . . 248

Streszczenie . . . . . , , , . . . , 255

* Present address: Academy of Physical Education, Dept, of Biology, Warsaw 45, Marymoncka 90. 


\section{INTRODUCTION}

Reports have appeared in literature for some considerable time on the subject of the possibilities of the endocrine activity of the salivary glands (B u d g es, 1928)

During the period from 1929-1944 Japanese research workers (O g a t a, 195.): I to et al., 1955; 1956) published a large number of studies based on physiological, biochemical and histochemical methods, in which they stated that the salivary glands, in addition to their secretory activity (digestive), are also endocrine glands. In addition, in 1944 they obtained from salivary glands a biologically active substance of a proteinous nature, affecting the calcification of hard tissues and capable of reducing the level of calcium in the blood. This substance, considered to be the specific hormone of the salivary glands, was termed by them parotin.

As is well known, the parathyroid glands are the ductless glands specialiy responsible for the phosphorus and calcium supply to the organism. I have not, however, encountered in literature, studies of the interdependence of these two glands (salivary glands and parathyroid glands), the activity of which is connected with the level of calcium in the blood serum.

\section{REVIEW OF LITERATURE}

In $1909 \mathrm{Parh}$ on and Golds tein devoted considerable space in their hardbook on endocrinology to the group described by Mik ulicz (1892), characterised by the symmetrical hypertrophy of the salivary and lachrymal glands. They stated that this disease is connected with the thyroid gland ( $\mathrm{P}$ a r h o n et al., 1957).

Parhon \& Kag a n (1923), in their investigations of the parotid salivary glands, showed that the nuclei of the cells lining the lumen of the discharging ducts are situated in the apical part of the cell, while they found accumulating secretion in the basic parts of the cells ( $\mathrm{Parh}$ on et al., 1957). These observations made it possible to reach the conclusion that the secretion of these salivary glands is discharged not, as is usually the case, into the lumen of the duct, but into the surrounding connective tissue or to the vessels.

Since that time numerous studies have been published by the Rumanian school of $\mathrm{Parh}$ on on the salivary glands and their connection with other ductless glands (P a r h o n et al., 1955-1957).

Since 1928 the problem of the salivary glands has occupied the attention of a large number of Japanese research workers. O g a t a endeavoured to find the answer to the question as to whether ductless activity of the salivary glands exists. In the first place he suspected that the salivary glands play a certain part in diabetes and connected their secretion with carbohydrate metabolism.

In connection with the above observations, experiments were initiated on animals and since that time numerous reports have appeared in world literature on the subject of the interdependence between the salivary glands and the endocrine glands (G r a ndos, 1951; H a r vey, 1952; R a y a u d, 1954 a, b; A bou h a r b, 1955; Bixter et al., 1957, 1959; A tkinson, 1959; Shafer et al., 1960; Soszka \& K raw c z u k, 1960 a, b; K a w a d a, 1962).

L a c ass a $\mathrm{n}$ e (1940) was the first to find sex dimorphism of submaxillary salivary glands in mice. The salivary gland of the male characterised by the predominating number of granular tubes, while the salivary gland of the female has a more vesicular structure. (The submandibular salivary gland in rodents consists of serous vesicles and tubes, in which the presence of granular matter has been confirmed and which were formerly termed mucous vesicles. As histochemical methods 
have not demonstrated the presence in these elements of mucus, they are now termed granular tubes). This author injected female mice with male sex hormones (testosterone) and male mice - with female sex hormones (folliculine). Under the influence of testosterone the salivary gland of the females takes on the type of the male structure, while the salivary gland of the males changes to the female type under the influence of folliculine. The result obtained by the experiment made it possible for the author to conclude that different factors which depend on the sex of the animal, exist in the saliva.

$\mathrm{T}$ a k i $\mathrm{zaw}$ a observed that there is an interdependence between the function of the salivary glands and the bony system ( $\mathrm{T} \mathrm{a} \mathrm{k} \mathrm{i} \mathrm{z} \mathrm{a} \mathrm{w} \mathrm{a,} \mathrm{1954;} \mathrm{G} \mathrm{a} \mathrm{b} \mathrm{e,} \mathrm{1950).}$

In $1940 \mathrm{Fuk} \mathrm{us} \mathrm{him} \mathrm{a} \mathrm{found} \mathrm{considerable} \mathrm{changes} \mathrm{in} \mathrm{the} \mathrm{teeth} \mathrm{of} \mathrm{mice} \mathrm{and} \mathrm{rats}$ with induced saliva deficiency ( $\mathrm{g}$ a $\mathrm{t}$ a, 1955). I s h i i (1944) described these changes by means of histological methods ( $\mathrm{g}$ a $\mathrm{ta}, 1955)$. The same year $\mathrm{Og}$ a $\mathrm{ta}$ isolated a fraction of active substance from the salivary glands of a bull, and injected young rats with this substance. In this experiment he observed an increase in hard tissues and a reduction in the level of calcium in the blood serum. Ito and $\mathrm{Miz} u \mathrm{tan}$ called this substance, which was in the nature of a protein soluble in water, parotin (I t o, 1954).

In 1949 I t o obtained crystalline formations from parotin, and in 1952 together with $\mathrm{Og}$ a $\mathrm{t}$ a gave a description of this substance, which was acknowledged tu be specific hormone of the parotid salivary gland ( $\mathrm{g}$ a $\mathrm{t} a, 1955)$.

G a be (1950) observed atrophy of the salivary glands in white rats where the pituitary gland had previously been removed by operation. Besides and A h a$z$ a $1 \mathrm{i}$ showed that after excision of the salivary glands the number of acidophilous cells in the pituitary gland increases. These cells disappear after parotin is administered.

$\mathrm{R}$ a y $\mathrm{n}$ a u d (1954 b) found that excision of the suprarenal gland in rats causes atrophy of the parotis.

Valeri (1954 a, b) gave rats testosteron and then examined its effect on the salivary glands. He found that the cellular nuclei enlarged in the secreting sections. As is well known, enlargement of the cellular nuclei is both a test and an index of the increased activity of the cell. He observed distinctly smaller cellular nuclei in castrated animals compared to the control animals.

$\mathrm{P}$ a r h on et al. (1956) gave rabbits, an extract prepared from the parotis of a bull and found that the extract was capable of raising the sugar conten in the blood.

$\mathrm{P}$ a r h o n et al. (1955 a) removed the parotid salivary glands of rats, then examined the effect of the absence of these glands on the testicles. They found that unilateral removal of the parotis caused compensatory a hypertrophy of the remaining part of the gland, but did not cause any changes in the testicles. On the other hand, after bilateral removal of the parotis, a distinct reduction in the processes of spermatogenesis were observed.

Godet (1956) found an interdependence in the mole between the development of parotis and the sexual glands. He reached the conclusion that the height of the epithelium of the secretory vesicles in the salivary glands depends to a certain extent on the hormone secreted by the testicles.

In recent years histological studies have been published in which use was made of histochemical technique or radio-active isotopes.

Dewey (1958) investigated, by means of histochemical methods, the parotis of the white rat after the pituitary gland had been removed. He found changes not only 
in the vesicular cells, which become smaller, but also changes in the contents of glycogen, RNA, PAS, specific esterase and the sulphydryl groups.

O g a a (1955), T a k z a wa (1954) found an increase in the epithelium of the thyroid vesicles after excision of the salivary glands in the white rat.

S a w i c k i (1961), using $\mathbf{J}^{131}$ on rats, observed increased accumulation of iodine in the thyroid gland of the animals as a result of the removal of the salivary glands. The author found less deposition of $J^{131}$ in the thyroid glands of animals which had been given parotin.

Sas aki et al., 1953; Dzierżykray-Rogalska \& Gutsze (1963) using phosphorus $\mathrm{P}^{32}$, examined the bones of white mice after the salivary glands had been removed and parotin administered.

No cells which could be responsible for the ductless secretory activity have, as yet, been found in the salivary glands. Golia n itzky (1924) considered that the hormonally active cells are the basket cells. During the last 30 years numerous histological, physiological and biochemical studies of the salivary glands have been published by the Japanese school (I t o, 1954, 1960; R a u c h, 1959; Eng l is h, 1960; Fleming, 1960; Fujki et al., 1960; Godlowski et al., 1960; Levi - Montalcini et al., 1960; Myant, 1960; S chneider et al., 1960; Sreebny, 1960; A s a o, $1961 \mathrm{a}, \mathrm{b}$; B a baeva et al., 1961; Innes et al., 1961; Quintarelli et al., 1961). As shown by these studies, the salivary glands must be included in the ductless glands group, but the majority of the authors do not give their opinion as to the place in the salivary glands in which the hormone is formed. According to O g a t a, the secretion of the salivary glands formed in the vesicles, flows through the intercalar ducts to the striated ducts and is there partly absorbed together with the hormone by the epitheloid cells lining the lumen of the tubes. Next the secretion reaches, though these cells, the lymphatic areas surrounding the striated duct. In the cells lining the lumen of the striated ducts there is a specific system of mitochondria, and canals lying parallel to them, which is indicative of the absorptive capacity of these cells. The absorptive activity of the cells described (Og a $t a, 1955)$ was also demonstrated by injecting protein solution into the main ducts of the parotis. At the same time, that same protein solution was injected subcutaneously, and the rapidity of the appearance of the protein administered in the blood was compared. It was found that absorption of the protein injected into the ducts, takes place six times more rapidly in comparison with the absorption of this solution given subcutaneously.

$\mathrm{Kr}$ a cht (1960), who gave the experimental animals parotin, found changes within the parotid salivary glands which led to the conclusion that the vesicular cells are connected with ductless secretory activity.

I to (1960) in analysing the activity of different salivary glands found that ductlees secretory activity is exhibited only by the parotid and submaxillary salivary glands. It seemed, in that author's opinion, that the sublingual salivary glands do not participate in secretory endocrine activity. Parotin is a hormone produced chieily in the parotis.

It is clear from the literature on salivary glands referred to above -- that these glands secrete a hormonally active substance capablae of calcifying hard tissues and of altering the level of calcium in the blood serum.

As we know the parathyroid glands play a dominant part in -phosphorus-calcium regulation.

It is assumed that the parathyroid glands belong to the group of ductless glands with a function mainly metabolic, that is, glands, the activity of which would appear 
to depend on the level of certain substances in the body fluids. (A stimulus to these glands is the reduced level of the substances regulated by them e.g. hyperfunction of the supra-renal cortex is caused by too low a level of natrium).

The slightest qualitative or quantitative fluctuations of ionized calcium are capable of causing serious disturbances in the system therefore, an expression of these processes should be morphological changes taking place in the parathyroid glands (Morgan, 1936; Forster, 1943 a, b, 1946; A bderhalden, 1952; Harvat, 1954; Eger, 1954; B a r g m a n , 1939; E l kin to n, et al., 1955; Lich w itz et al., 1955; T a l mage et al., 1955; Krook, 1957; Weymouth, 1957; Grau, 1958; Lange, 1961; F u j i i, 1960 a, b; H art wi g, 1962).

It is however, generally known that evaluation of parathyroid gland function by morphological methods is very difficult.

The chief classification of the cells of the parathyroid glands is based on the study made by Sandström (1880), who while describing the parathyroid glands was the first to, observe two types of cells - cells rich in cytoplasm and cells with a small amount of cytoplasm. The next was Welsh (1889) who in describing the cells rich in cytoplasm termed them main cells, and the second kind, poor in cytoplasm, oxyphil cells. Getzow a (1907), divides the chief cells of the parathyroid glands into light (Wasserhelle Zellen) and dark (Rosarote Zellen) according to the affinity of the cytoplasm to dyes. In addition she distinguishes acidiphilous cells and syncytial cells.

B o be a u (1914) found in the horse a considerable variety of cell types, such as basic cells, normal cells. light and dark cells, large granular or colloidal celis, syncytial bodies, protoplasmatic and spongiocytes.

In 1935, Castlem an and M a 11 or y distinguished between parathyroid cells, dividing them into dark and light cells, which unite into a common group of chief cells (normal). They also distinguish oxyphil cells, dividing them into light and dark cells. According to these authors the parenchyma of the gland consist mainly of dark chief cells. The light chief cells found in the periphery of the gland occur in very small amounts.

Correi a M a d e ir a (1942) took the comparative histology of man and mammals as a basis for classification of the cells. His classification is similar to that of Castleman and M a 110 ry (Correia M a d ira, 1942-1946).

While there is still certain agreement in the views of authors as to the morphological classification of the glandular cells of the parathyroid glands, the question of the origin and function of each cellular type still remains unexplained.

Since the appearance of the first description of the parathyroid glands discussion has continued on the problem of which of the cells, chief or oxyphil, are the secreting elements.

Pepere (1906) described the cycle of transformation of the parathyroid ceils, which leads from the chief cell to the oxyphil secretory cell and back. He considered the oxyphil cell the most active, and held that it is a changed chief cell characterised by high secretory activity ( $\mathrm{R}$ u c a $\mathrm{t}, 1949$ ).

In 1919 Bergstrand, and later $\mathrm{H}$ offheinz (1925) came to opposite conclusions: they considered the oxyphil cell to be degenerate cells deprived of a secretory function. This concept was to find an increasingly large number of adherents among histologists, and in particular among histopathologists ( $\mathrm{u}$ c a r t, 1949).

B e r g m a n n (1939) considers that the light chief cells and dark chiefs cells are secretory elements, while the oxyphil cells formed from them are degenerating 
inactive forms, which in the continued process of degeneration may undergo fatty degeneration.

A large number of authors (R os of, 1934; de R o bertis, 1940-41; I g n a ti eva, 1948; Rucart, 1949; Hansler, 1953; Czerski, 1952; DzierżykrayRog a lska, 1954; 1958; W iśniewski, 1960; H a ra et al., 1957; 1959; 1962), consider that all the cells occurring in the parathyroid glands are the same type of cell at different functional stages.

$\mathrm{R}$ o s of (1934) in his investigations of the structure of the parathyroid glands in rats depending on age, pregnancy and diet, stated that histological changes in the glands of different groups of animals are slight. The differences consist rather in the arrangement of the cells than in their kind. He distinguishes in the rat, chief cells, light cells and chromophilous cells, and considers that the chief cells are formed from light cells. The latter are, he considers, inactive cells. In the control animals the author found that only $5 \%-25 \%$ of the cells were in the secretory stage. He is of the opinion that the cellular organelle such as the Golgi apparatus and chondriom, which are subject to changes in structure during the secretory cycle, play an active part in cellular secretion.

Correia Madeira (1942-1946) has made a large number of detailed cytological studies based on investigation of the Golgi apparatus and distribution of the chondriom, discussing the effect of the fixing fluid used on the picture obtained. He considers that only the dark chief cells (which he terms chief cells) and the light chief cells are of functional significance. The number of light cells encountered in the gland served him as a criterion of the functional state of the gland. He gives an detailed description of the Golgi apparatus and chondriom, but does not give his opinion on the participation of these organelle in cellular secretion. The author aid not find a constant polar position of the Golgi apparatus, either in relation to connective tissue or in relation to the blood vessels. The variable structure of the Golgi apparatus in the secretory cycle of the cells of the parathyroid glands has, also been dealt with by a large number of research workers ( $\mathrm{Courvi}$ er et al., 1922; Dias-Amado et al., 1944; de Robertis et al., 1940-1941; Rucart, 1949).

B ensly (1947) investigated the parathyroid glands of dogs, from which she removed part of the glands, causing hypertrophy of the remaining part. The auihor endeavoured to find pre-secretory granular matter within the cells. In her opinion they occur in three forms: a) vacuoles staining very faintly, b) granules stained intensively and c) colloidal globules. She did not, however, find any connection between secretory function and the cytoplasmatic formations examined.

I g n a t i e v a (1948) who investigated the parathyroid glands of manmals (dogs, cats, rabbits, guinea pigs and white rats) found that homogeneous cells occur. She is of the opinion that the process of the endocellular production of the secretion is manifested morphologically by the presence, in the cytoplasm, of small vacuole: which gradually fuse and form light fields. After complete dilution of the cytoplasm, the secretion flows into the blood vessels. The cell, which is in the final stage of accumulating the secretion, appears as a completely light formation, greatly enlarged. I $\mathrm{g}$ a t i e v a considers that the whole cytoplasm is responsible for the production of the secretion, and not different organoids such as, for example, chondriom or the Golgi apparatus.

For tin a (1948) induced rickets in rats and found that oxyphil cells appeared, which are known to occur rarely in rats. The appearance of oxyphil cells, was in the author's opinion, evidence of increased activity of the gland. 
R u c art (1949), taking comparative histology as his basis, introduced his own classification of types of cells in the parathyroid glands. From the embryonic cell, from which the basic cell is formed, the author distinguished two series of cells differing from each other morphologically and functionally:

A) Light series: a) basic cell, b) non-staining cell with a small number of vacuoles, c) non-staining cell with a large number of vacuoles, d) light cell.

B) Dark series: a) basic cell, b) chromophilous cell, c) oxyphil cell, from which the granular oxyphil cell or the oxyphil cell with vacuoles may be formed.

$\mathrm{Rucart}$ on the basis of his own research reached the conclusion that the parathyroid glands secrete at least two hormones. One of them would be formed in the vacuoles (light series), and the precursor of the second would be fuchsinophil granules (dark series). According to this author both series of cells occur in the normally functioning glands of higher mammals. In the lower mammals the parathyroid glands are formed chiefly of basic cells, and it is only under sperial conditions (pregnancy, experiment) that cells appear which can be allocated to the light or dark series. In addition, he found that the oxyphil cells can possess secretcry activity.

$\mathrm{H}$ ans ler (1953) using caryometric methods, investigated the parathyroid glands of white rats subjected to different experiments, consisting in the stimulation and inhibition of the gland function. The author notices that inhibition of the gland function was manifested by a reduction in the size of the nuclei. The nuclei became enlarged in the stimulated gland. Similar methods of research were used by other authors, who are of the opinion that caryometric methods give more reliable resulcs in investigations on gland function than morphological methods ( $\mathrm{de} r$ et al., 1955); $\mathrm{H}$ a d le $\mathrm{r}$ et al., 1962).

Eder \& H a r l 1 (1955) give an exact classification of parathyroid cells and their evolutionary capabilities. By stimulating the parathyroid glands they increased the size of the nuclei, after which they defined the nuclear-cytoplasmatic ratio. On the basis of their experiments they endeavoured to determine the connection between the type of cell and its function, using morphological and statistical methods. The morphological observations of the authors were concerned with the appearance of the nuclei. On the basis of studies made by Altm a n (1955) who found that protein (globulin) metabolism in the cell is connected with the changes taking place in the nuclei, the authors divided the nuclei occurring in the cells of the parathyroid glands into four types:

1) nuclei, which contain nucleoli situated centrally (resting nuclei),

2) nuclei, which contain nucleoli situated next to the nuclear membrane (usuaily these are larger nuclei preparing to secrete nucleolar substance to the cytoplasm!,

3) nuclei visually almost empty, without distinct chromatine substance,

4) nuclei in which nucleoli and chromocentres can be seen situated under the nuclear membrane (type 3 and 4, are nuclei exhausted by intensive secretory activity).

At the same time, they made a statistical analysis of the 4 types of cellular nuclei described above, using the Chalkley method, counting about 1000 cellular nuclei in one group. On the basis of statistical analysis they reached the conclusion that enlargement of the nucleus is a sign of its activity, while its reduction in size indicates a decrease in cellular function. These authors, taking variations in the size of the nuclei as a basis, consider oxyphil cells to be inactive cells, dividing them into two groups; dark cells and light cells. They are of the opinion that the light oxyphil cell is formed from the dark oxyphil cell. 
In recent years many studies have appeared concerning the nistochemical investigation of the parathyroid glands (Pearse et al., 1958; $\mathrm{Samnazzari}$ et al., 1959; W a t th ar d, 1960; Fuj i, 1960; Y ang, 1960; $\mathrm{Z}$ aw is tow ski, 1962).

Tremblay et al., showed in 1959, using the histochemical technique, that oxyphil cells in the parathyroid glands of humans and monkeys are distiguished by intensive activity of oxygenating enzymes (DPND, TPND, succinic acid dehydrogenase). The results obtained suggest that the oxyphil cells are intensively functioning cells. This does not mean that their secretory activity is greater, it is possible that the oxyphil cells have simply accumulated enormous energy. Their function and significance, however, have not as yet been thoroughly investigated.

Literature on this problem shows that there are many experimental studies on the submandibular salivary glands and their connection with other endocrine glands. As yet, however, little attention has been paid to the parotid salivary glands and the changes taking place in them under the influence of the functioning in other ductless glands. Not many authors have dealt with the changes in the endocrine glands caused by experimental hypofunction or hyperfunction of the parotid salivary glands (Hypoînction of the salivary glands - asialadenism, is caused by their partial or total removal, hyperfunction - hyperasialadenism, by the transplantation of the glands or by injecting parotin).

Although there is an enormous amount of literature on the parathyroid glands, and the morphological and histochemical changes within these glands under the influence of different factors have been thoroughly investigated, yet I have not encountered studies dealing with the changes taking place in them under the Influence of hyperfunction or hypofunction of the salivary glands, apart from the short reference made to them in the work by Ogat a (1955).

\section{MATERIAL, METHODS AND TECHNIQUE}

The material used in the present study consisted of 185 young white rats (sexually mature males) weighing from $130-160 \mathrm{~g}$., which were kept on a standard granulated diet. ${ }^{1}$ )

The animals were divided into IV groups. Each group was subjected to differert experiments:

In group I, an investigation was made into the effect of removal of the parathyroid glands on the morphological picture of the salivary glands of the white rat.

In group II, an investigation was made into the effect of the removal of the parotid salivary glands on the morphological picture of the parathyroid glands.

In the animals in group III the morphological picture of the parathyroid gland; and parotid salivary glands was investigated after the administration of parotin.:)

In group IV, $\mathrm{P}^{32}$ was used to investigate the effect of removal of the salivary glanids and doses of parotin on the bones of the rats.

In each of the above groups some of the animals were used as controls.

The animals were anaesthetized with ether and then dissected, the parotid salivary glands and parathyroid glands being taken for examination. One salivary gland and one parathyroid gland were always fixed in Lison-Vokaer fluid, the other,

1) Granulated fodder for rats (Institute of Medicine, Warsaw): Wheat mash $19^{\circ} / 0$, barley mash $19 \%$, oat mash $19 \%$, wheat bran $20 \%$, fish meal $8 \%$, skimmed powdered milk $8 \%$, fodder yeast $5 \%$, casein $1 \%$, vitamin mixture $1 \%$.

2) The author is extremely grateful to the firm of Teikoku Mfg. Co, Tokio, for supplying the parotin used in the present study, free of charge. 
depending on the later procedure, was fixed in one of the following fluids: Bouin. Helly, Aoyamo, sublimate, Carnoy neutral formol. The prepared glands were soaked in paraffin, and sections 5 microns thick were next stained by the following methods:

a) haematoxylin-eosine - to obtain normal specimens for examination,

b) the Azan and Mallory method,

c) Best's method - to reveal the presence of glycogen,

d) PAS method - to discover the presence of mucopolysaccharides (NC M a $n \mathrm{us}$, 1948),

e) Müller's method, as modified by $\mathrm{Gr}$ a u $\mathrm{m}$ a $\mathrm{n} \mathrm{n}$ and $\mathrm{Cl}$ a u s $\mathrm{s}$ - using colloidal iron - to discover the presence of acid mucopolysaccharides (P e a rs e, 19.77; Gr a u m an et al., 1958),

f) Feulgen's method using Schiff's reagent - to estimate the degree of poly merisation of desoxyrybonuclein acid (DNA) - (Cas pers o n, 1950; K r y gier, 1940),

g) Brachet's method (mixture of pyronin B and methyl green) as modified by Godle wski \& Vorbrodt (1954), using perchloric acid to discover the presence of RNA (B r a c he t, 1957),

h) Laguess's method - to discover the presence of argentophilous fibres ( $R$ o$\mathrm{m}$ e is, 1953),

i) Regaud's method (ferrous haem.) - to discover the presence of cellular chondriom,

j) sections obtained after fixing material in Aoyamo fluid were used to discover the presence of the Golgi apparatus.

IV. EFFECT OF THE REMOVAL OF THE PARATHYROID GLANDS ON THY MORPHOLOGICAL PICTURE OF THE SALIVARY GLANDS OF THE WHITE RA?

Fifty sexually mature male white rats were used for the experiment, in forty of which the parathyroid glands were removed by operation. The remaining 10 rats were used for control purposes, control group A consisting of 5 rats left intact, and group B, 5 rats on which a blank operation was performed. The rats deprived of their parathyroid glands were killed at different intervals after the operation.

\section{i. Operation technique}

The rats were anaesthetized with ether and placed on their backs on a special operating table ( $\mathrm{F}$ a $\mathrm{r}$ is et al., 1949). An incision was made into the skin along the os hyoideum to the manubrium sterni. The salivary glands were prepared upwards, musculi sterno-cleido-mastoidei prepared sideways and the short muscles of the neck were cut in front of the trachea. After the cut muscles had been drawn apart by hooks the trachea and thyroid gland could be seen. The parathyroid glands could be seen in the upper poles of the thyroid, more to the back, in the place where the upper thyroid artery penetrates into the parenchyma of the gland. During the first period of the experiments the parathyroid glands were removed from the animals together with the surrounding tissue of the gland, which caused frequent haemorrhages from the upper thyroid artery (G o u d a l, 1955; S n e 11, 1956). On this account in later operations, after the parathyroid glands had been revealed, they were 
grasped with small forceps and the peduncle of the gland ligated, next excising the parenchyma of the gland, as far as possible in its entirety. Clinical symptoms of insufficiency of the parathyroid glands occured with uniform intensity after the operation had been performed in the above way. After sprinkling penicillin into the wound, the skin was sewn up with continuous catgut suture.

Before the animals were killed their blood samples were taken by caraiiac puncture in order to define the calcium content in the serum. The calcium level was calculated by means of the flame photometer (Model III made by the firm cf Carl-Zeiss), previously drawing the curve of calibration for calcium.

During dissection cuttings were taken from the parotid salivary glands in five permanent places. At the same time the thyroid gland was removed, after which it was cut in series in order to check that the parathyroid glands had been completely excised.

\section{Description of material}

The animals in this group were divided as follows:

Control A - intact animals

Control B - animals after blank operation

Group I - animals killed during the first week after operation

Group II - animals killed from 2-4 weeks after operation

Group III - animals killed in the 6th or 7th week after aperation

5 animals

5 animals

15 animals

15 animais

10 animals

Total 50 animals

Control animals - (Controls A and B) calcium level in the blood serum was on an average $10 \mathrm{mg} \%$.

The parotid salivary gland of control animals is a vesicular-serous gland.

The histochemical tests made reveal the presence of a fairly considerable amount of RNA in the basic parts of the vesicular cells (Fig. 1, Plate X). No glycogen was discovered. Staining with colloidal iron revealed the presence within the vesicular cells of parotis of a large amount of acid mucopolysaccharides. Within the cells of the intercalar ducts slight PAS - granular matter was observed. The striated ducts formed of cylindrical cells arranged very regularly side by side, did not give any of histochemical reactions applied. When staining by the Regaud method was used, parallel lines of striation became visible within the striated saliva ducts in the basic part of the cells, which according to certain authors is cellular chondriom (Fig. 2, Plate X).

Group I - animals killed during the first week after operation. Calcium level in the blood serum was on an average $7.1 \mathrm{mg} \%$.

The structure of the secretory sections of the gland is similar to that of the glands of the control animals. Within the interlobular ducts an apparently double-layered epithelium, the internal layer of which flakes off into the lumen of the duct in the form of a ribbon is observed (Fig. 3, Plate X). Distinct differences in comparison with the control occur after applying histochemical tests. A marked decrease is observed in the RNA 
contents at the base of the glandular cells. When colloidal iron is used the vesicles of the salivary gland also stain, but very delicately, scarcely perceptibly.

The animals in this group ceased eating, became restless and exhibited excessive excitability as early as the day following the operation. In the following days the occurrence of fibrotic twitches of the muscles lasting for several minutes was observed. Attacks of convulsions recurred in the operated animals with different degrees of intensity.

G rou p II - animals killed in the second, third or fourth week after operation. The average figure for the calcium level in the serum was $7.5 \mathrm{mg} \%$.

The changes are the most distinct in this group of animals. In animals which were killed during one of the recurring attacks of convulsions, in addition to the normally formed lobes of the parotid glands there are lobes of very greatly altered structure (Fig. 4, Plate X). The change in structure consists in the glandular cells being greatly reduced. In this way vesicles with a fairly large lumen are formed, which makes them somewhat similar to the vesicles of the thyroid gland (Fig. 5, Plate XI). In addition the cytoplasm of the cells is very strongly vacuolised, and their nuclei become pycnotic and are thrust towards the base (Fig. 6). The lumen of such a new-formed vesicle is filled with the granular secretion. The striated ducts have a similar appearance (on account of the large lumen and flattened epithelium), and can be recognised by means of the irregular shapes and greater amount of connective tissue which surrounds them.

In the later weeks after the operation (3rd and 4th) connective tissue with a large amount of fatty cells can be observed to penetrate between the changed visicles (Fig. 7, 8, Plate XI). Vacuolisation of the vesicular cells disappears during this period, the cells become flatter and their nuclei pycnotic. A similar process takes place in the striated ducts. The secretion observed in the lumen of the vesicles also slowly disappears. In the gland changed in the above way all the histochemical tests gave negative results (RNA, PAS, Müller's method, Best's method).

G roup III - animals killed in the 6 th or 7 th week after the operation. The calcium level in the serum was on an average $8.1 \mathrm{mg} \%$.

The parotis in the animals of this group is built normally of lobes, differing in that the vesicular cells and their nuclei are smaller and that numerous mitoses, which are not observed in the other groups of animals, occur within the striated ducts. In addition to the normally built lobes of the salivary gland, aglomeration of fatty tissue is observed to have (Fig. 9, Plate XI), formed in place of the glandular lobes which have disappearea', the striated ducts however remaining. 


\section{Results}

1. The parotid salivary glands of rats after excision of the parathyroid gland exhibit distinct morphological and histochemical changes.

2. As early as the first week after the operation flaking of the epitheial ribbons is observed into the lumen of the interlobular ducts. The amount of RNA and acid mucopolysaccharides within the glandular cells decreases.

3. From the second to the fourth week after the operation great changes are observed within certain lobes. The glandular cells are reduced, and their protoplasm undergoes intense vacuolisation. The lumen of the vesicles increases, making them similar to the vesicles of the thyroid gland. The nuclei of these vesicular cells become pycnotic. Secretion appears in the lumen of the vesicles and striated ducts and disappears in the fourth week.

4. In the sixth and seventh week the glandular lobes are built of vesicles, the cells and nuclei of which appear to be smaller. The parotis of animals from this period give very faint histochemical reactions (RNA and colloidal iron). Numerous mitoses appear within the epithelium of the striated ducts. Lobes of fatty tissue, with remaining striated ducts running through them, are encountered in addition to the glandular lobes.

5. The results of the investigations made justify the statement that after removal of the parathyroid glands, morphological changes occur in the parotid salivary glands of the rat indicating the disappearance of glandular tissue in favour of fatty tissue.

\section{EFFECT OF THE REMOVAL OF THE PAROTID SALIVARY GLANDS} ON THE MORPHOLOGICAL PICTURE OF THE PARATHYROID GLANDS

Seventy sexually mature male white rats were used for the experiment, of which the parotid salivary glands were removed in 60 animals, and 10 animals were used as controls. The animals deprived of the parotid salivary glands were killed at different periods of time after the operation, and the parathyroid glands were then taken, fixed and stained according to the methods already discribed.

\section{Operation technique}

The rats were anaesthetized and operated on in a position similar to that described in the case of the removal of the parathyroid glands. A lengthwise incision made into the neck revealed the salivary glands. Preparation of the parotid salivary glands presented great technical difficulties, since in the rat they are situated in close connection with the deep vessels of the neck, which can easily be damaged during the operation. In addition their recesses reach the angles of the 
mandibule and partly surround the external ear ducts. The Loeventhal glands, which had to be left, intact, were often closely connected with the salivary glands (W a l ker, 1958; M i n a mi et al., 1959; Dzi erź kray-Rogalska et al., 1960; Le e s o n, 1960). Removal of the parotid salivary glands was therefore begun by separating the blood vessels of the neck, then the Loeventh a 1 gland was released, the recesses of the parotis separated and the parotis removed in one block. After removal of the salivary glands the small bleeding vessels were ligated, the wound sprinkled with penicillin, and the skin firmly sewn up with continuous catgut suture.

\section{Description of material}

The animals in this group were divided as follows:

Control A - animals left intact

Control B - animals on which a blank operation was performed

Group I - animals killed during the first week after the operation

Group II - animals killed in the second week after the operation

Group III - animals killed in the thired week after the operation

Group IV - animals killed in the 4th or 5 th week after the operation

5 animals

5 animals

15 animals

15 animals

15 animals

15 animals

Total

Controls A and B.

70 animals

The parathyroid glands of rats are built of two kinds of cells: a) dark cells, b) light cells, (a third kind of cells - the oxyphil cells - appear, as already stated only under special conditions).

The dark cels [corresponding to the dark cells of $\mathrm{R}$ o s of (1934) and B e ns le y (1947), chief cells of R u c a r t (1949) and the second type of cells given by $\mathrm{Czerski}$ (1952)]. These cells are most numerously represented and it is they which form the parathyroid gland. Their size varies from $8-10$ microns. The limits of these cells are not distinct $a n d$ their shape may vary from multilateral to pyramidal and irregular. The cellular cytoplasm is filled with small densely arranged granular matter. The nuclei of the cells exhibit considerabe polymorphism. They can be variform nuclei, spherical or even elongated, and large. These nuclei are surrounded by a distinct nuclear membrane, and certain of them stain hyperchromatically (Fig. 10, Plate XII).

The Golgi apparatus in these cells is fairly abundant, most often lying on the apical pole of the cell (we take that part of the cell supported by blood vessels (to be the base).

In addition to the dark cells described, there are light cells in each gland forming the peripheral part of the parathyroid gland. The light cells are larger than the dark, their limits are more clearly visible and the cellular nuclei, usually large, have a distinct chromatin stroma and tautly stretched thin nuclear membrane. The cytoplasm of these cells is fillcd with small less densely distributed granular matter and vacuoles of different size, which together give the impression of light cytoplasm. It 
must be emphasised that this picture depends to a great degree on the fixing medium used. The cytoplasm of cells fixed in Lison-Vokaer fluid retains the small, loosely scattered, granular matter and as a result is slightly darker. After fixing in Bouin fluid the granular matter referred to disappears completely and the cells then give the impression of light, empty, and vacuolised formations. These cells are often arranged in clumps. The histochemical methods used did not permit of discovering significant differences between the two types of cells.

The pictures of the parathyroid glands of control groups $A$ and $B$ do not differ from each other.

G r o u p I - parathyroid glands of rats killed during the week following removal of the parotid salivary glands.

No perceptible morphological changes are found in the parathyroid glands of this group of animals. Only the presence of a dual kind of nuclei in the dark cells is distinct, particularly after using the Feulgen reaction to DNA. Some of them are larger, sometimes vesicular with delicately scattered chromatin, others smaller, irregular in shape and more hyperchromatic.

G r o u p II - parathyroid glands of rats killed two weeks after removal of the parotid salivary glands.

The parathyroid glands were still built of two kinds of cells: dark and light cells. As in the case of the glands in the control animals, the dark cells lie chiefly in the central parts of the gland but occupy a far smaller part of it. On the other hand the periphery of the gland, formed of light cells, undergoes considerable growth.

The cells (light) situated peripherally are very often arranged in clumps or pseudo-vesicles with a very small lumen in the middle (Fig. 11, Plate XII). The cytoplasm of these cells is lighter in comparison with analogical cells observed in the control glands. The chromatin stroma is clearly visible in the majority of the irregularly oval-shaped nuclei.

A characteristic feature is the occurrence in the cells of the parathyrcid glands of this group of animals of both mitoses (Fig. 12, Plate XII) and amitoses (Fig. 16, Plate XIII). The phenomenon is almost totally unencountered in the control animals. In addition, both in the ceniral parts and in the peripheral glands, "restlessness" of the nucleus is observed, many of the nuclei possessing a thickened, and sometimes folded nuclear membrane.

A frequent phenomenon here is also the occurrence of large nuclesli situated in the immediate vicinity of the nuclear membrane, which gives the impression of the nucleolar material being secreted into the cytoplasm.

The above pictures are repeated in all the glands of this group of animals. 
The Brachet method made it possible to discover the scanty RNA granular matter scattered over the whole cytoplasm. This granular matter is often grouped in the apical part of the cell, above the nucleus, in the cells situated peripherally, and in addition the presence of PAS positive granules was detected in these cells (Fig. 13, Plate XII).

The Golgi apparatus in the cells is situated in the apical part (the basic part of the cells is supported by the connective tissue or blood vessels) and is composed of thick trabeculae (Fig. 14, Plate XIII).

Grou p III - parathyroid glands of rats killed in the third week afte: removal of the parotid salivary glands.

The parathyroid glands of this group of animals are very similar in appearance to those described in group II. It would, however, seem that more cells with PAS + granular matter are encountered in the periphery. By using Best's method it proved possible to discover single granules of glycogen in this group of animals also.

G rou p IV - the parathyroid glands of rats killed in the fourth and fifth week after removal of the parotid salivary glands.

The parathyroid glands of the animals in this group are also compused in the central part of dark cells with somewhat elongated nuclei. The light cells lying peripherally, as in the control animals, are arranged in clumps. These cells now have a slightly different appearance: they are high, almost cylindrical, large, and mainly supported at their base by blood vessels. The nucleus is situated in the basic part of the cell (Fig. 15 . Plate XIII). As was the case in group II, nuclei in course of preparation for division are abserved.

During this period a third kind of parathyroid element appears - the oxyphil cells. These are cells with intensively acidiphilous cytoplasm and hyperchromatic nuclei, situated in bands or clumps (Fig. 16, Plate xiII).

The Golgi apparatus in these cells is situated, similarly to that in the control animals, on the apical pole. It is formed of single delicate trabeculae and small fragments arranged round the nucleus (Fig. 17, Plate XIII).

It would seem that this gland as a whole is enlarged compared to that in control animals. At the same time penetration is observed from the periphery of bands of connective tissue, which separate it from the smaller and larger lobes.

\section{Results}

1. The parathyroid glands of rats from which the salivary glands have been removed exhibit morphological and histochemical changes. 
2. The changes begin to occur in the second week after removal by operation of the salivary glands and affect the cellular nuclei in the first place. The following are found:

a) presence of nuclei preparing for amitosis

b) a large number of caryokinetic figures

c) increase in the number of large nuclei

d) characteristically large nucleoli situated in the immediate vicinity of the nuclear membrane.

3. The peripheral part of the gland formed of light cells undergoes considerable growth.

4. The light cells increase in size.

5. Oxyphil cells arranged in clumps appear.

6. It would seem that the changes described above, and in particular the presence of numerous cell divisions the increase in size of the nuclei and cells, constant arrangement of the nucleoli near the nuclear membrane and the increase in the number of light cells, makes it possible to reach the conclusion that the parathyroid glands, after removal of the salivary glands, exhibit features which are evidence of the stimulation of these glands.

VI. EFFECT OF ADMINISTERING PAROTIN ON THE MORPHOLOGICAL PICTURE OF THE PARATHYROID GLANDS AND PAROTID SALIVARY GLANDS

The animals in this group were given intramuscular injections of $0.1 \mathrm{mg}$. or $0.2 \mathrm{mg}$. of parotin per $100 \mathrm{~g}$. body weight during the course of $7-14$ days. All the rats were fed on a standard diet. Dissection of the animals was performed 24 hours after the final injection, and 12 hours after the last feed.

During dissection specimens were taken from the parotid salivary glands and the parathyroid glands. The material was fixed and stained by the methods described in Section III.

The animals which received parotin were divided as follows:

Group I consisted of 5 control animals, which were given $0.2 \mathrm{mg}$. saline solution per $100 \mathrm{~g}$. body weight, daily for 14 days.

Grou p II was composed of 10 animals which were given $0.1 \mathrm{mg}$. of parotin per $100 \mathrm{~g}$. of body weight, daily for 7 days.

Group III consisted of 10 rats which were given $0.2 \mathrm{mg}$. of parotin per $100 \mathrm{~g}$. of body weight, daily for 7 days.

The fourth group was formed by ten animals which were given $0.2 \mathrm{mg}$. of parotin per $100 \mathrm{~g}$. body daily for 14 days. A total of 35 animais were used for the experiment. 


\section{A. PARATHYROID GLANDS}

\section{Description of material}

The picture of the parathyroid glands of rats which were given parotin, in groups II, III and also IV, is similar. The whole of the gland appears to be formed of cells of one kind only, that is, from dark cells with dense and fine-grained cytoplasm, and as a result it is impossible to distinguish the peripheral part from the central part of the gland. The cellular nuclei give the impression of being more hyperchromatic. They differ in shape but are not large, and the nuclear membrane is thick and often folded (Fig. 18, Plate XIV). Morphologically these cells are similar to the dark cells described above in the parathyroid glands of control arimals, but they appear to be smaller. The whole gland also appears to be smaller. Histochemical investigations, to discover the presence of RNA acid, acid mucopolysaccharides or PAS reaction did not give positive results.

The Golgi apparatus in the cells of the parathyroid glands is also situared in the apical part of the cells and has the appearance of a scattered formation (Fig. 19, Plate XIV).

\section{Results}

1. The parathyroid glands of rats which were given parotin exhibit morphological changes consisting in the reduction in size of the nuclei, an increase in density of the cytoplasmatic granulations and reduction in the number of light cells.

2. The changes described do not vary with the dose and period of time during the parotin is given.

3. Changes occur in the structure of the gland as early as on the severith day ater the injection of parotin.

\section{B. PAROTID SALIVARY GLANDS}

\section{Description of material}

The morphological pictures of the parotid salivary glands of rats given par'stin are identical in groups II, III and IV, but differ from the salivary glands of the control animals. In comparison with the control salivary glands, the nuclei of the cells forming vesicles alter their appearance in the animals in this group, and appear to be smaller. They also change in shape, become variform and not infrequently a folded and tickened nuclear membrane can be observed. The sporadically encountered round 
nuclei also have a thick and slackly stretched nuclear membrane. After parotin is administered enlargement of the blood and lymphatic vessels situated near the striated ducts is observed to occur (Figs. 20, 21, Plate $\mathrm{XV})$.

In comparison with the salivary glands of the control animals, the argentophilous fibres within the gland, which surround both the striated ducts and the blood and lymphatic vessels lying near them with numercus coils, increase in number.

After applying the Brachet reaction distinct reduction is observed of the amount of ribonuclein acid in the basic parts of the glandular cells (Fig. 22). The presence of PAS + granules is observed in the apical parts of the cells and also in the cells of the intercalar ducts (Fig. 23, Plate XV).

When histochemical methods were used the striated ducts gave no reaction.

\section{Results}

1. The parotid salivary glands of rats which were given parotin, exhibit both morphological and histochemical changes occurring with uniforn intensity, irrespective of the dose or period during which parotin is administered.

2. The changes observed occur in the gland as early as seven days after the first dose of parotin.

3 . The above changes, reduction in size of the cellular nuclei, reduced pyronin absorption, increase in the amount of connective tissue) are evidence of the weakened activity of the salivary glands of rats which have bcen given parotin.

\section{THE EFFECT OF REMOVAL OF THE SALIVARY GLANDS}

AND ADMINISTERING PAROTIN ON THE AUTORADIOGRAPHIC PICTURES OF THE BONE OF WHITE RATS

The experiments described above show that the parathyroid glands intensify their activity as a result of the absence of parotid salivary glands. Parotin administration causes morphological signs of functional inhibition both of the parathyroid glands and the parotid salivary glands. We were of the opinion that the morphological changes of the glands investigated should be reflected in the changes taking place in the skeletal system. On this account, several experiments were made using radioactive $\mathrm{P}^{32} .{ }^{3}$ )

3) The work was carried out in collaboration with L. Gutsze, M. Sc., in the Medical Physics Department of the Medical School, Białystok. 


\section{Description of material}

A total of 30 young white rats kept on a standard diet were used for the investigations, and were divided into the following 6 groups:

'Group I - control animals.

Group II - animals from which the parotid salivary glands had been removed, and dissection made a week after the operation.

Group III - animals which were dessected 2 weeks after the removal of the salivary glands.

Group IV - animals which were dissected 3 weeks after removal of the salivary glands.

Group V - animals which were given $0.1 \mathrm{mg}$. of parotin per $100 \mathrm{~g}$. body weight, daily for 7 days.

Group VI - animals which were given $0.2 \mathrm{mg}$. of parotin per $100 \mathrm{~g}$. of body weight daily for 7 days.

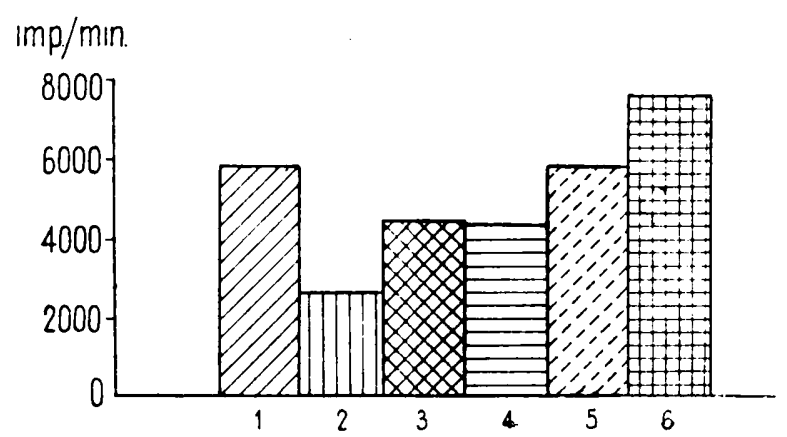

Fig. 24. Diagram of the activity of bone ash calculated by means of a Geiger-Muiller counter.

1 - Control. $2-7$ days after removing of salivary glands. $3-14$ days after removing of salivary glands. $4-21$ days after removing of salivary glands. $5-$ After injections $0.1 \mathrm{mg}$. of parotin. $6-$ After injections $0.2 \mathrm{mg}$. of parotin.

In order to trace the behaviour of phosphorus in the bones, radio-active phosphorus was used in the experiment, injecting 0.08 micro-Curies $\mathrm{P}^{32}$ $\left(\mathrm{Na}_{2} \mathrm{H}^{32} \mathrm{PO}_{4}\right.$ - alkaline sodium phosphate) per $1 \mathrm{~g}$. of body weight. The tibiae of each animal were prepared, one of which (the right) was burnt in a muffle stove at a temperature of $900^{\circ} \mathrm{C}$., and the number of impulses calculated from the ash obtained by means of a Geiger-Müller counter. The results obtained are shown on Fig. 24.

Micro-sections were made from the epiphysis of the second bone (left. tibia) in order to obtain autoradiograms, which were made by the Pelc method using AR-10 Kodak emulsion. After developing the picture on the emulsion photographs was made by the contact method. The results 
obtained from the above experiment are shown on Figs. 25-30 (Plate XVI).

The largest number of impulse: in the bone ash were obtained in Group VI of the animals (which were given $0.2 \mathrm{mg}$. of parotin for 7 days). The autoradiographic picture of the base of the bones in this group of animals exhibits the greatest degree of blackening of the film.

The smallest number of impulsas from bone ash were obtained in group II, i.e. of the animals from whici the parotid glands had been removed. These results were confirmed by the autoradiographic picture, which exhibits very faint blackening of the film in the bases of the bones in this group of arimals.

\section{Results}

1. The greatest activity in bone ash was obtained in the animals from group VI (which were given $0.2 \mathrm{mg}$. of parotin), and the autoradiographic picture corresponds to this.

2. The smallest number of impulses were obtained in bone dust in group II of the animals (animals killed one week after removal of the salivary glands), and the autoradiographic picture corresponds to this.

\section{STATISTICAL ANALYSIS OF MATERIAL}

Evaluation of the activity of the parythyroid glands based on morphological methods is difficult, and therefore statistical methods were used in the expectation of obtaining more far-reaching results, which might confirm or extend the morphological observations described above. ${ }^{4}$ )

As shown in the descriptions contained in the preceding sections, the parathyroid glands of animals from which the parotid salivary glands had been removed, are in a stimulated condition. The administering of parotin caused changes in the parathyroid glands constituting evidence of the inhibition of their activity. As is well known, one of the phenomena occurring with increased activity of the ductless glands is the observed enlargement of the nuclei. Reduction of activity, on the other hand, is characterised by the distinct reduction in the size of the nuclei.

We were interested in whether a statistical analysis based on data obtained from counting the nuclei occurring in a permanent field of vision would confirm the changes in size of the nuclei in the parathyroid glands of animals in different experimental groups.

4) The statistical analysis of the material was made in the Institute of Statistical Mathematics of the Maria Curie-Skłodowska University in Lublin, under the direction of Prof. Dr. Mikołaj Oleki e wi c z. 
Table 1.

Mean number of nuclei for each rat.

\begin{tabular}{|c|c|c|c|c|c|c|c|c|c|c|c|c|c|c|}
\hline \multicolumn{5}{|c|}{ Control / $\mathrm{K} /$} & \multicolumn{5}{|c|}{ Removal of sallvary glands /U/ } & \multicolumn{5}{|c|}{ Parotyna / $z /$} \\
\hline \multirow{2}{*}{$\begin{array}{l}\text { No. } \\
\text { of } \\
\text { rat }\end{array}$} & \multicolumn{3}{|c|}{$\begin{array}{c}\text { Pertpheral part of gland, } \\
\text { field of vision }\end{array}$} & \multirow{2}{*}{$\begin{array}{l}\text { Central } \\
\text { part of } \\
\text { gland }\end{array}$} & \multirow{2}{*}{$\begin{array}{l}\text { No. } \\
\text { of } \\
\text { rat }\end{array}$} & \multicolumn{3}{|c|}{$\begin{array}{c}\text { Peripheral part of gland, } \\
\text { fteld of vision }\end{array}$} & \multirow{2}{*}{$\begin{array}{l}\text { Central } \\
\text { part of } \\
\text { Rland }\end{array}$} & \multirow{2}{*}{$\begin{array}{l}\text { No. } \\
\text { of } \\
\text { rat }\end{array}$} & \multicolumn{3}{|c|}{$\begin{array}{c}\text { Peripheral part of gland, } \\
\text { fleld of viston }\end{array}$} & \multirow{2}{*}{$\begin{array}{l}\text { Central } \\
\text { part of } \\
\text { Bland }\end{array}$} \\
\hline & 1st & 2nd & Total & & & $1 \mathrm{st}$ & 2nd & Total & & & $10+$ & 2nd & Total & \\
\hline 23 & 80.00 & 91.00 & 85.50 & 89.00 & 53 & 68.00 & 72.07 & 70.32 & 0.3 & $1<4$ & 73.67 & 80.33 & 78.00 & 78.67 \\
\hline 24 & 83.00 & 92.33 & 87.67 & 71.67 & 52 & 80.33 & 77.00 & $78 . \epsilon^{\top}$ & 72.00 & 125 & 73.67 & 83.67 & 78.67 & 77.00 \\
\hline 49 & 52.33 & 57.00 & 54.67 & 56.33 & 112 & 74.33 & 81.33 & 77.83 & 72.67 & 127 & 76.33 & 80.33 & 78.33 & 82.67 \\
\hline 45 & 70.00 & 77.33 & 73.67 & 71.33 & 51 & 77.67 & 71.00 & 74.33 & 65.00 & 85 & 74.33 & 81.57 & 78.00 & 82.00 \\
\hline 114 & 89.67 & 103.00 & 96.33 & 84.00 & 62 & 64.00 & 63.00 & 03.50 & 64.33 & 83 & 88.67 & 68.33 & 78.50 & 77.00 \\
\hline 48 & 66.00 & 70.00 & 68.00 & 73.00 & 60 & 63.00 & 58.67 & 60.83 & 55.67 & 81 & 74.33 & 80.00 & 77.17 & 76.67 \\
\hline Total & 73.50 & 81.78 & 77.64 & 74.22 & Total & 71.22 & 70.61 & 70.92 & 65.50 & Total & 77.17 & 79.05 & 78.19 & 79.00 \\
\hline
\end{tabular}


Material was collected consisting of 18 rats, 6 in each of the. groups examined, as follows:

Group I - control $(K)$,

Group II - animals from which the parotid glands had been removed $(U)$,

Group III - animals which were given injections of parotin ( $Z$ ).

Three different micro-sections were taken from each parathyroid gland of observation. Calculation was made of the number of cellular nuclei in three fields of vision on each section, measurements always being made of two fields lying opposite each other on the periphery of the section and of one field in the centre of the section. In this way measurements of the number of nuclei in nine fields of vision were obtained from one parathyroid gland. In order to count the number of nuclei in a constant field of vision a micrometric objective mesh was placed in $15 \times$ magnifying ocular, thus obtaining a squared field with 11 horizontal and 11 vertical lines. The preparations were observed with an immersion objective obtaining $1500 \div$ magnification.

The number of cellular nuclei occurring on 11 horizontal and 11 vertical lines were counted in each field of vision. In addition the nuclei occurring on the points at which the two lines crossed, were counted, the total number of nuclei occurring on the crossing were deducted from the sum of all the nuclei present in the give: field of vision, obtaining in this way the true sum total of nuclei occurring in one field of vision.

The first task was to calculate the mean numbers of the nuclei for each animal of the three groups.

Since it would seem from morphological observations that the cells lying in the periphery of the gland react far more quickly to the stimuli by a change in their size and appearance than the cells lying in the central parts of the gland, the mean numbers of nuclei for each of the animals were calculated separately for the central and peripheral fields of vision, using in the first case 6 fields of vision, and in the second, 3 fields of vision. These mean numbers of nuclei for each rat are given in table 1. In addition, in the bottom line of table 1 the mean numbers of nuclei in the periphery and centre of the sections are given for each of the three groups of animals (Table 1).

The relations shown in table 1 are illustrated by diagram (Fig. 31) representirg the distributons of the series of the mean numbers of nuclei. Each point represents a seperate animal, and the position of this point higher or lower, the place of the animal in its group.

Parotin acts on the parathyroid gland, primarily in the peripheral parts of the gland (Fig. 31). In the group of animals given parotin the mean of nuclei of the parathyroid cells exhibit hardly any variation, concentrating strictly around one figure - 78 , while in the control group the dispersion of the mean numbers of nuclei is very considerable in relation to the concentration described. This means that the doses of parotin act in two directions - in the animals with mean numbers of nuclei greater than 78 this factor reduces their averages to the figure of 78 . In animals with mean numbers of nuclei smaller than 78 , this factor increases their averages to the figure 78. This conclusion is further borne out by the variations found in the mean numbers of nuclei in the control group (in this group half the animals had mean values far above 78 , and half far below 
78). It may therefore be taken that the group of animals injected with parotin would have exhibited a dispersion of averages similar to the control group, if they had not been given parotin.

In the central parts of the sections (Fig. 31) a similar effect of parotin is found, but not to the same degree as in the periphery. Analogical concentration round the number 78 occurs in four animals, the two remaining animals concentrating round 82 . It may be assumed here that

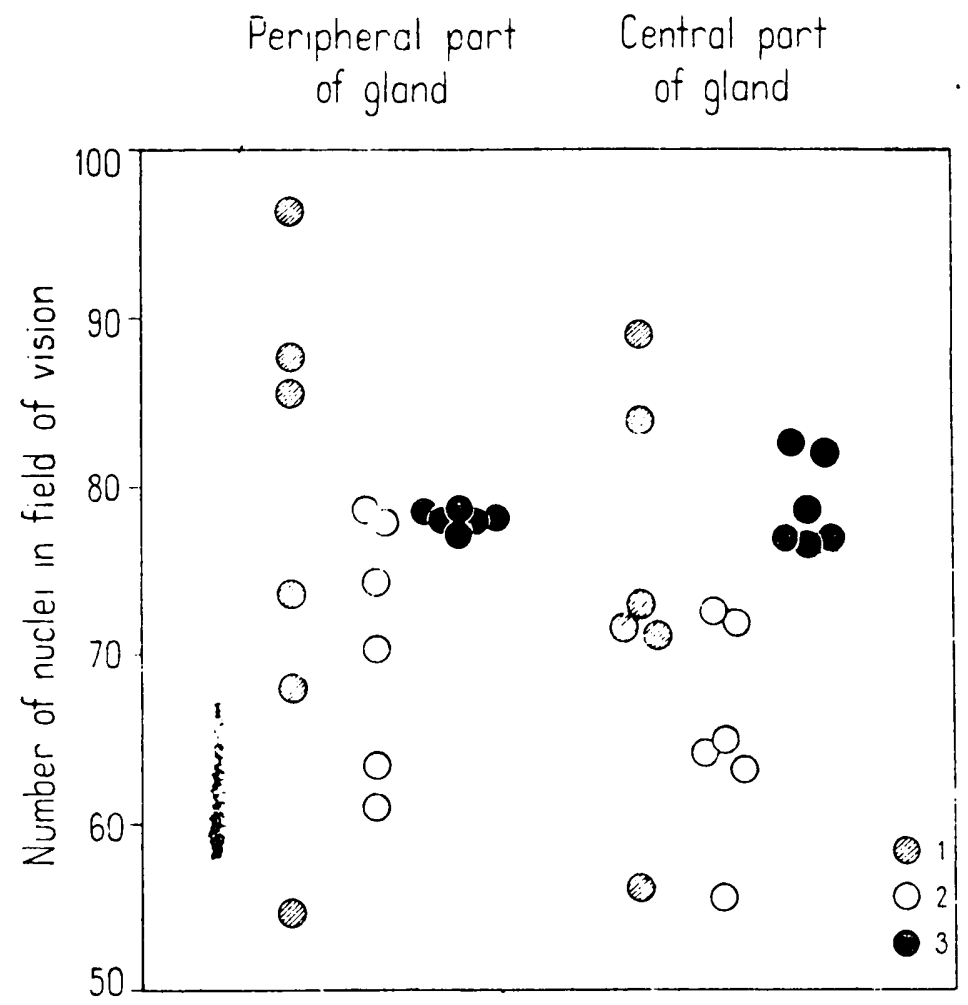

Fig. 31. Mean number of cellular nuclei in the parathyroid glands of rats.

1 - Control. 2 - Rats with salivary glands removed. 3 - Rats with injections of parotin.

the effect of parotin on the central parts of the gland is weaker than on the peripheral parts, particularly where one of the two directions of action is concerned, the reduction of the number of nuclei in animals with high mean values.

Assuming that the greater the number of nuclei observed in the field of vision, the smaller their dimensions, and vice versa (with a constant ratio of nuclei-cytoplasm) it may be stated that in the parathyroid glands 
with, on an average, large nuclei, that parotin acts in the direction of reducing their dimensions. In parathyroid glands with on an average small nuclei parotin induces their enlargement. It must therefore be presumed that the first action (reducing) is stronger than the second (enlarging). What is very striking is that the effect of parotin on the periphery tends to equalise the mean dimensions of cellular nuclei in the parathyroid glands of different animals to a certain dimension corresponding to the number of 78 nuclei in a field of vision.

The effect of excising the salivary glands is also interesting. This efiect, as can be seen from diagram (Fig. 31), is exerted, it is true, in one direction, but it is exerted selectively. This influence consists in the enlargement of the mean sizes of the nuclei, but rather in those animals only in which these mean values are small (i.e. mean number of nuclei is large). This influence is apparent both in the periphery and in the central parts of the gland.

The question arises as to whether the two-direction action, or selectivity, of the influences of experimental factors on the mean dimensions of the nuclei exists within the peripheral or central parts of each gland as well as between glands. Within the scope of action of one factor total variability (either in the periphery or in the centre of the glands) consists of variability between animals and of the mean variability within the animals, and the latter in the mean variability between sections and the mean variability within the sections. The "mean squares" in the hierarchic variance analysis (Federer, 1955) are the comparative measures of these different variabilities. In the terminology used in this analysis the questions put would read: do the experimental factors reducing the mean squares between animals also reduce the mean squares within the animals, i.e. the mean squares between the sections and the mean squares within the sections? The answer to this question is given by table 2 , which contains the results of three hierarchic variance analyses made separately for the control group and experimental groups. Table 2 shows the following facts:

$1^{0}$ The dominating component of total variability in control group (K) and in the group of rats with their salivary glands removed $(U)$ is formed by the differences between rats, particularly in the peripheral parts of the gland, e.g.: in group $(K)$ the mean square between rats (1378) is nearly 13 times greater than the mean square within the rats (110).

$2^{0}$ In the peripheral parts of the glands in group (K) and in group (U) the differences between sections do not create an additional variation which could not have resulted from the variation within the sections, since, for example, in group $(K)$ the mean square between sections (124) is only slightly greater than the mean square within the sections (101). It 


\section{Table 2.}

Hierarchic analysis of variance.

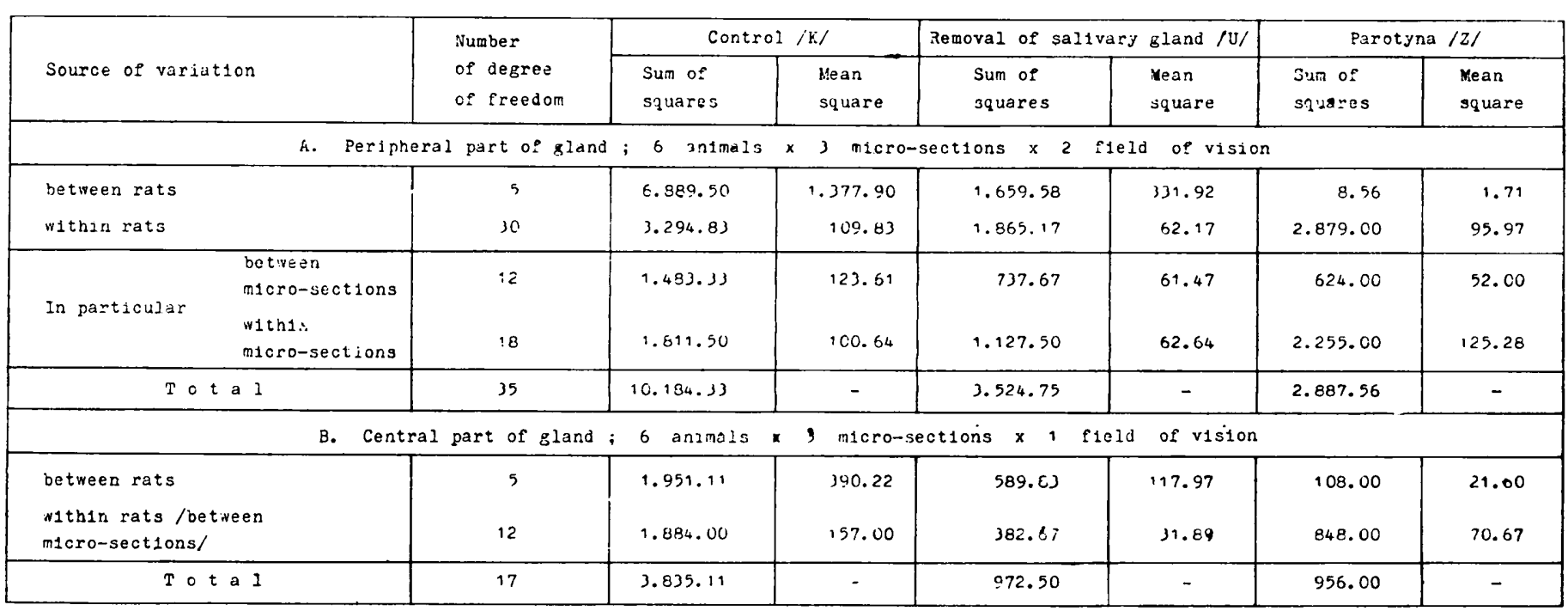


may therefore be said that there are no significant differences between the sections.

$3^{0}$ In the group given parotin $(Z)$ differences in the mean number of nuclei between the rats disappear, falling far below their random variability which would have resulted from the variability within the glands. This phenomenon occurs particularly distinctly in the periphery of the gland, where the mean square between the rats falls to the figure 2, while the mean square within the rats is 96 . The difference between micro-sections also falls below random variation which would have resulted from variations within the sections, but to a far lesser and non-significant degree than the differences between animals. These facts give evidence of the intensive equalising action of parotin.

Table 3.

Comparison of mean squares in the experimental groups and in the control group.

\begin{tabular}{|c|c|c|c|c|}
\hline \multirow[b]{2}{*}{ Comparison or mean squares } & \multicolumn{2}{|c|}{ Comparison of the control grup /F/ } & \multirow[b]{2}{*}{${ }^{*} 0.05$} & \multirow{2}{*}{$\begin{array}{l}\text { ilumber of } \\
\text { degree of } \\
\text { freedom }\end{array}$} \\
\hline & $\begin{array}{l}\text { witb the group } \\
\text { with salivarj } \\
\text { glands removed } / \mathrm{U} /\end{array}$ & $\begin{array}{l}\text { witb the group } \\
\text { given injections } \\
\text { of parotin } / 2 /\end{array}$ & & \\
\hline \multicolumn{5}{|c|}{ h. Peripheral part of eland } \\
\hline $\begin{array}{l}\text { between rats } \\
\text { within rats }\end{array}$ & $\begin{array}{l}4.15 \\
1.77\end{array}$ & $\begin{array}{r}804.85 \\
1.14\end{array}$ & $\begin{array}{l}5.05 \\
1.83\end{array}$ & $\begin{array}{r}5 ; 5 \\
30 ; 30\end{array}$ \\
\hline $\begin{array}{ll}\text { between } \\
\text { micro-sections }\end{array}$ & $\begin{array}{l}2.01 \\
1.61\end{array}$ & $\begin{array}{l}2.38 \\
1.24\end{array}$ & $\begin{array}{l}2.69 \\
2.22\end{array}$ & $\begin{array}{l}12 ; 12 \\
18 ; 18\end{array}$ \\
\hline \multicolumn{5}{|c|}{ B. Central part of gland } \\
\hline $\begin{array}{l}\text { between rats } \\
\text { within rats } \\
\text { /owtween alcro-sections/ }\end{array}$ & $\begin{array}{l}3.31 \\
4.92\end{array}$ & $\begin{array}{r}18.07 \\
2.22\end{array}$ & $\begin{array}{l}5.05 \\
2.69\end{array}$ & $\begin{array}{l}5: 5 \\
12: 12\end{array}$ \\
\hline
\end{tabular}

Table 3 gives the results of comparison of the experimental groups with the control group from the aspect of:

1) variations between animals and 2) variations within the animals.

In the peripheral parts of the glands variation within the animals ivas divided into variations:

a) between micro-sections, and b) within the micro-sections.

In the central part of the glands the variations between micro-sections correspond to the variations within the animals.

In each case comparison was made of the mean squares in groups $U$ and $Z$ with the mean squares in group $K$ ( $F$ is h e r, 1957).

Generally speaking, the mean square within the rats was reduced significantly only in group $U$, being reduced to a far greater extent in the 
central parts of the glands than in the peripheral parts. In group $Z$ this reduction, despite the fact that it is not significant, is also greater in the central part of the glands.

The equalising action of parotin was most distinctly marked, particularly in the peripheral parts of the glands. Removal of the salivary glands had a far lesser influence, and this influence manifested its equalising action in a different way.

The maximum equalising action of parotin was evident in the differences between animals. These differences were in fact eliminated, arid also the differences between micro-sections were reduced, even if to a considerably smaller, still to highly significant degree. The differences within the micro-sections were rather increased by parotin (although notsignificantly) so that the differences as a whole within the animals remained unchanged in comparison with the control group.

The equalising effect of removal of the salivary glands on the differences between the animals was slightly greater in the periphery in comparison with the central part of the glands. Although this difference cannot be considered significant ( 4.15 and 3.31 - from table 3 ), it is a phenomenon analogous to the stronger effect of parotin on the periphery than on the central parts of the glands.

If on the other hand we put a question of the equalising effect of the experimental factor on the differences between micro-sections, it is particularly here that this effect proved to be most marked, but only in the central parts of the glands, where it is even more marked than on the differences between animals, which is a converse phenomenon to that in the case of parotin.

Thus while the equalising action of parotin primarily affects the differences between animals and is far stronger in the periphery than in the central part of the glands, the effect, generally far weaker, of removal of the salivary glands primarily equalises the differences between micro-sections and rather in the central parts of the glands.

One important fact remains to be emphasised, that is the absence of significant differences between micro-sections in all three groups (Tab. 2). This fact gives evidence of the great similarity of structure of nicro-sections from different places in the same gland, although the micro-sections have different properties in the periphery and in the centre of the gland. This is of great importance to the research worker, since it gives rise to the assumption that regardless of the part of the gland from which the micro-section is taken, this micro-section is fully representative of the structure of the whole gland in the given animal.

This assumption should of course be additionally checked by taking sections from different defined places in the gland. 
On the other hand differences between animals, i.e. differences between the structures of different glands, are very large.

If the absence of significant differences between the micro-sections were confirmed by special experimentation, it would then appear that the most correct procedure in research on the parathyroid gland is to take the greatest number of animals and limit the number of micro-sections taken to two only, or even to one micro-section from each animal - of course taking into consideration separately the peripheral and central parts of the micro-sections.

\section{CONSIDERATION OF' RESULTS AND DISCUSSION}

This study was intended to supply an answer to the question as to whether there is a connection between the parathyroid glands and the parotid salivary glands - which are connected with the calcium-phos-

Table 4.

Plan showing results of investigations.

\begin{tabular}{|l|c|c|c|}
\hline & $\begin{array}{l}\text { Parotold sal1- } \\
\text { vary glands }\end{array}$ & $\begin{array}{l}\text { Parathyro1d } \\
\text { Elands }\end{array}$ & $\begin{array}{l}\text { Activity of bone ash and } \\
\text { autoradiographic picture } \\
\text { of the bases of bones } \\
\text { after administering }\end{array}$ \\
\hline $\begin{array}{l}\text { Femoved of } \\
\text { farathyroid glands } \\
\text { Kemoval of parotid } \\
\text { salivary glands } \\
\begin{array}{l}\text { Injection of } \\
\text { paratin }\end{array}\end{array}$ & - & + & - \\
\hline
\end{tabular}

phorus metabolism of the organism. With this aim in view a series of experiments were made.

The results of the investigations have been set out in plan form in table 4.

As shown by the experiments made, the absence of the parathyroid glands causes considerable morphological changes in the parotid salivary glands of white rats. These changes occur in the secretory vesicles, the lumen of which at first enlarges considerably, and later becomes filled with finegrained secretion (Fig. 4). Vacuoles appear in the vesicular cells, then the cells flatten. At the same time the connective tissue, with a large amount of fatty cells, penetrates between the changed vesicles of the gland. As the process continues, only fatty tissue is observed in the place of the lobes with altered structure, and numerous striated ducts can be seen in the fatty tissue as the residue of the glandular lobes (Figs. 8, 9). 
The morphological pictures described above lead to liquidation of part of the glandular lobes, and in consequence to partial withdrawal of the salivary glands from their function.

The views held by different authors on the structure of the parathyroid glands do not agree. It is true that there is a certain coincidence of views on the morphological classification of the glandular cells, but the fact that in different mammals slightly different types of cells occur, complicates the situation.

The majority of authors sonsider that no oxyphil cells are observed in the parathyroid glands of lower mammals in their normal state. These cells are only found in certain pathological conditions induced by experiment. Fortina (1948), for instance, noticed the appearance of cells with acidophilous cytoplasm in the parathyroid glands of rats after rachitis had been induced in these animals. Castle man \& Mallory (1935), B a r g m a n n (1939), C or r e i a M a d eir a (1942) hold the view that oxyphil cells are degenerative elements formed from the chief cells. This view is supported by $\mathrm{Hamperl}(1950)$, who stated that oxyphil cells are formed by a special kind of degeneration to which the cells of other glands are also subject. Analogical cells filled with eosinophilous granulations (oncocytes) are found in the thyroid, pituitary and suprarenal glands.

A description has been given in the present investigations of the presence of two kinds of cells (dark and light) in the parathyroid glands of the control rats, and the additional appearance of cells with acidiphilous cytoplasm in the glands of animals from which the parotid salivary glands had been removed (similar cells were observed by Eder, 1961). We cannot give an opinion as to the origin of the cellular forms described, since this still remains a debatable question, despite the application to research on this problem of both electronic microscopes and sensitive histochemical and enzymatic investigations. It would, however, seem that all these cells develop from one type of cell, and the differences in appearance depend on a different functional state. The histochemical methods we used did not assist in the solution of this problem, but it would appear that the increase observed in the number of light cells - considered as active cells (in the peripheral parts of the glands) and of oxyphil cells, the presence of a large number of nuclei preparing for amitosis and frequent mitoses (Fig. 12), and also the position of the nucleolus near the nuclear membrane, form sufficient grounds for concluding that the parathyroid gland goes through a period of intensified activity after the removal by operation of the parotid salivary glands.

A statistical analysis made it possible in addition to establish dispersicn of the mean numbers of nuclei in the parathyroid glands of rats with their 
salivary glands removed, and at the same time indicated the significarce of the deflection reducing the mean number of the nuclei referred to. This leads to the conclusion that larger nuclei occur in the parathyroid glands of this group of animals in comparison with the control group (Fig. 31).

The morphological pictures of the parathyroid glands of animals given parotin differ only slightly between themselves, but reduction of the part of the cellular nuclei observed, and also the reduction of the cells permits the assumption that these glands were subject to reduction as compared with the glands of the control rats. The morphological pictures described would therefore seem to show that the parathyroid glands, after parotin is administered, exhibit a distinct withdrawal from activity.

A statistical analysis showed that the effect of parotin is to render uniform the mean dimensions of the nuclei, causing as a result reduction in size of the large nuclei, but at the same time causing the enlargement of the smallest nuclei (Fig. 31).

The morphological pictures of the parotid salivary glands after injections of parotin also exhibit morphological features consisting in the reduction of the terminal sections and their nuclei. At the same time the disappearance of RNA from the basic parts of the vesicular cells can be observed, which gives grounds for concluding that the secretory activity of the gland is reduced.

A decrease in the activity of $\mathrm{P}^{32}$ was observed in the bone ash from rats from which the parotid salivary glands had been removed.

An increase in radioactive phosphorus was found in the animals which were given parotin. The autoradiographic pictures correspond in both groups to the numerical results.

As shown by the experiments made (Sections V and VI) supported by the results obtained from the statistical analysis, after removal of the parotid salivary glands stimulation of the activity of the parathyroid glands is observed. The injection of parotin, on the other hand, causes inhibition of the activity of the parathyroid gland.

The reply to the question why removal of the salivary glands causes hyperfunction of the parathyroid glands must be based on the process if reciprocal action of both glands. It must be accepted that the parathyroid gland is the master gland (producer) in relation to the parotid salivary gland. After removing the parotid salivary glands that is, the effector, the intensified activity of the parathyroid gland observed becomes understandable, and conversely, injection of parotin, that is, the induction by experimental means of a state of hyperfunction of the parotid salivary glands (the effector) caused blocking of the function of the parathyroid glands (the producer).

Assuming that the parathyroid glands are the master glands both in trie 
calcium-phosphorus metabolism of the bones (tissue effectors) and in relation to the parotid glands, the results described in Section IV become understandable. After removing the parathyroid glands (the producers) it was found that morphological changes take place in the parotid salivary glands indicating the atrophy of the glandular tissue, which may be evidence of the withdrawal of a certain part of the glandular parenchyma from functioning.

An attempt can be made to explain the functional connection of these two glands by referring to the pituitary gland. The majority of the authors dealing with the dependence of the parathyroid gland on the pituitary gland reach the conclusion, however, that the parathyroid glands possess far-reaching functional independence, based more on variations in the mineral metabolism than on connection with the pituitary gland. In analysing the role of the parathyroid glands in the hormonal system in respect to variations in mineral economy the conclusion must be reached that there is no direct connection between the parathyroid glands and other endocrine glands.

Connection of the endocrine function of the glands examined is more difficult since the existence of the parathyrotropic hormone remains a debatable question up to the present time. Parotin is also a hormone with multi-lateral action and there is no adequate proof that the endocrine. function of the salivary glands is subject to the direct influence of the pituitary gland. Connection of the changes observed to take place in both the glands described through the pituitary gland is therefore somewhat doubtful.

As a result of removal of the parotid saliyary glands a reduced level of $\mathrm{P}^{32}$ is observed in the bone tissue. Injection of parotin, on the othe; hand, causes considerable increase of radioactive phosphorus, as was established both by means of a Geiger-Müller counter and autoradicgraphically.

A very interesting problem is to find whether the parotid salivary glands act directly on the bone tissue or through the medium of the parathyroid glands.

Removal of the salivary glands causes on the one hand hyperfunction of the parathyroid glands (Section V) and on the other reduction of the level of $\mathrm{P}^{32}$ in the bone (Section VII). Injection of parotin inhibits the function of the parathyroid gland and at the same time influences the increased $\mathrm{P}^{32}$ content.

The question therefore arises as to what is the mechanism causing the changes described above.

The facts observed and described above allow me to offer two hypotheses. The first of these would indicate the direct influence of the 
parotid salivary glands on bone tissue, while the second possibility would refer to the inclusion in this mechanism, additionally, of the parathyrcid glands.

The direct influence of the parotid glands on the bone tissue is shown in the studies by Japanese authors (S a s a k i et al., 1953; O g a t a, 1955; I to et al., 1956). By injecting parotin - the hormone of the parotid salivary glands, distinct stimulation was obtained of the tissues of mesenchymatous origin and calcification of the hard tissues.

If, however, the parotid salivary glands are removed, a very characteristic reduction in the level of $\mathrm{P}^{32}$ is observed in the bone.

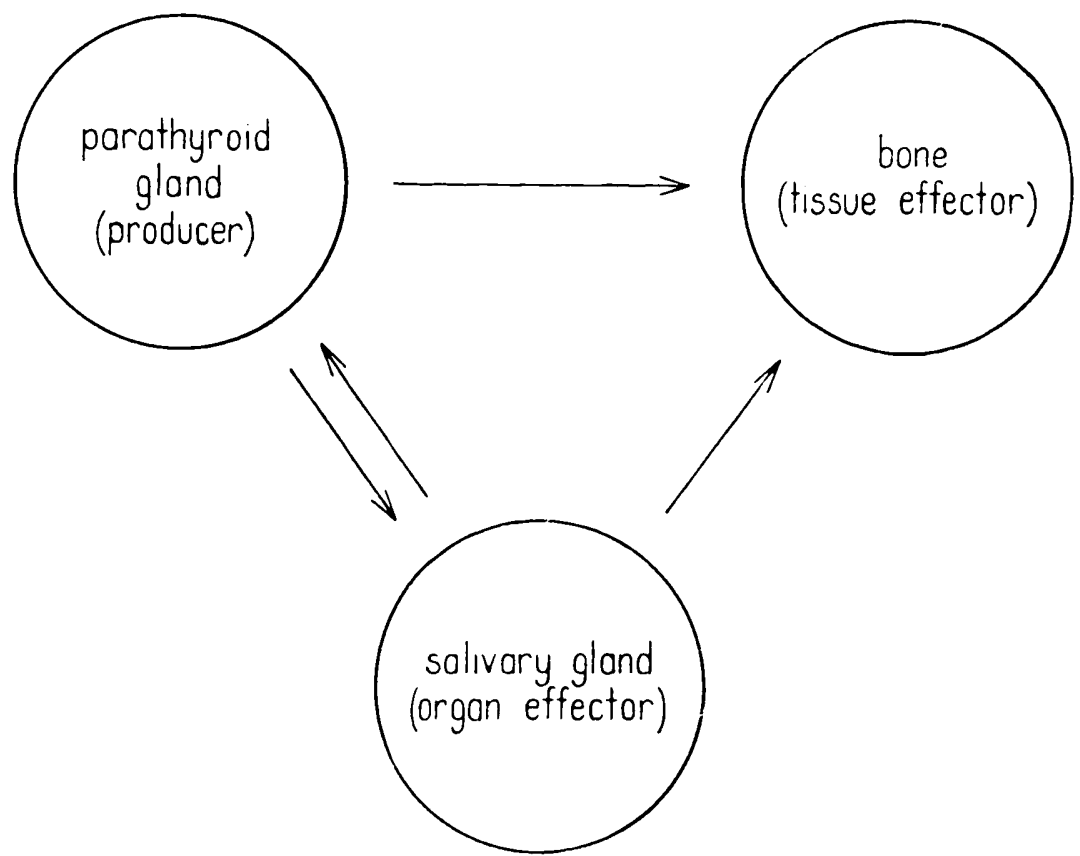

Fig. 32. Functional connections between the parathyroid glands, parotid salivary glands and bone tissue.

These facts emphasise the direct connection of the process of calcification of the bones with the parotid salivary glands.

At the present time there are no indisputable proofs of the direct action of the parotid salivary glands on the process of calcification of the bones, but the finding of changes in the functioning of the parathyroid glands both after removal of the parotid salivary glands and after giving parctin argues, on the basis of the function of the parathyroid glands known in physiology, in favour of the possibility of stimulation of the processes of calcification of the bones by the parotid salivary glands. 
The results obtained by the experiments concerning the changes in the parathyroid glands and parotid salivary glands indicate a functional interdependence between these two glands.

It is difficult on the basis of the facts given to form an opinion as to the role and hierarchic dependence of the parotid salivary glands and parathyroid glands in the calcium-phosphorus metabolism. The existence of the superiority of the parathyroid glands in the function discussed may however be suggested, the role of the salivary glands being then limited to that of a link in the chain of essential connections in mineral metabolism. At the same time this would be the role of organic effector of the parathyroid glands, the hypofunction or absence of which would lead to very significant damage to the calcium-phosphorus metabolism.

The functional connections between the parathyroid glands, the parotici salivary glands and bone tissue are illustrated by Fig. 32.

\section{SUMMARY}

The author studied the connection between the parathyroid glands and the parotid salivary glands - glands connected with the calcium-phosphorus metabolism of the organism. For this purpose she investigated:

1. The effect of removal of the parathyroid glands on the morphological picture of the parotid salivary glands.

2. The effect of removal of the parotid salivary glands on the morphological picture of the parathyroid glands.

3. The effect of injecting parotin on the morphological picture of the parathyroid glands and parotid salivary glands.

4. The effect of removal of the salivary glands and injection of parotin on the bones of rats. The investigations were made using $\mathrm{P}^{32}$.

5. In addition a statistical analysis was made of the material examined.

After remcval of the parathyroid glands atrophy of the glandular tissue occurs in favour of fatty tissue, which may be evidence of the withdrawal of certain parts of the glandular parenchyma from function.

As a result of excising the salivary glands, the following changes were caused in the parathyroid glands: enlargement of the dimensions of the glandular cells and the nuclei, the presence of numerous cell divisions, permanent position of the nucleolus near the nuclear membrane and increase in the number of light cells - the active cells. The above data indicate that the parathyroid glands exhibit symptoms of stimulation after the salivary glands have been removed.

After carrying out experiments consisting in administering parotin the following results were obtained: reduction of the nuclei, reduction of the pyronin absorption of the protoplasm, increase in the amount of connective tissue in the parathyroid glands and decrease of the cells and nuclei in the vesicles of the salivary glands. These observations are prouf of the enfeebled activity both of the parathyroid glands and of the salivary glands in rats given parotin.

Rats from which the salivary glands had been excised and rats which had been given parotin were used for the autoradiographic investigations. Using radioactive 
$\mathrm{P}^{32}$, examination was made of the influence of the above factors on the phosphorus level in the bones of the rats. The greatest activity in the bone ash was obtained in animals which were given $0.2 \mathrm{mg}$. of parotin per $100 \mathrm{~g}$. body weight over the course of one week. The autoradiographic picture agrees with these results. The smallest number of impulses was found in the bone ash of animals which were dissected one week after removal of the salivary glands, which corresponds to the autoradiographic picture.

The statistical analysis made of the material enabled the following to be established:

a) larger nuclei occur in the parathyroid glands of animals from which the salivary glands have been removed in comparison with the control animals.

b) neither very large nor very small nuclei are encountered in the parathyroid glands of animals as the result of the parotin injections given. It would seem that the parotin exerts an equalising effect, rendering the mean dimensions of the nuclei uniform.

As can be seen from the above data, removal of the parathyroid glands caused morphological changes in the parotid salivary glands which provided evidence of the withdrawal of these glands from the functioning.

On the other hand removal of the salivary glands caused hyperfunction of the parathyroid glands, and injections of parotin caused blocking of the function of the parathyroid glands.

The above results 'would appear to indicate the existence of reciprocal action of both glands, the parathyroid gland being the master gland (producer) in relation to the salivary gland (effector).

It is also clear from the experiments made that the salivary glands exert their influence not only on the parathyroid glands, but also on the bone tissue. Removal of the parotid salivary glands causes characteristic reduction of the $\mathrm{P}^{32}$ level in the bone, while injections of parotin causes an increase in $\mathrm{P}^{3: 2}$ content. On the basis of the results obtained the author puts forward two hypotheses as to the influence of the salivary glands on bones. According to the first of these the parotid salivary gland directly afiects the bone tissue, according to the second - it does so through the parathyroid glands, which, as is already known, then exert a decisive influence on phosphorus-calcium metabolism.

Acknowledgements: It is my pleasant duty to thank Docent Dr. H. J , e w in s k a, Head of the Dept. of Histology and Embriology, for the assistance and criticism during the preparation of this publication.

I should also like to thank Professor Dr. M. Olekie wi c z for his help in work on the statistical analysis. My sincere thanks are due to Dr. K. Odynie c for carrying out the microphotography, and Miss G. S t a c how s k a, for her technical assistance.

\section{REFERENCES}

1. A bderhalden, R., 1952: Die Hormone. Springer, Berlin, Göttingen, Heidelberg: $91-152$.

2. A bouh a r b, M., 1955: A propos du dimorphisme sexuel de la glande sous-maxillaire chez les Meriones (Rongeurs, Gerbillinés), C. R. Soc. Biol., 149: $1866-1868$.

3. A $1 \mathrm{tm}$ a n, H. W., 1955: Zur Morphologie der Wechselwirkung von Kern und Cytoplazma, Klin. Wschr., 33: 306-314. 
4. A s a no, H., 1961a: A Parotin-like substance (A-parotin) in bovine parotid gland. III. Studies on the physiological chemistry of the salivary glands. Endocr. Jap., 8: 199-204.

5. A s a n o, H., 1961b: A parotine-like substance (A-parotin) in bovine parotid gland. IV Studies on the physiological chemistry of the salivary glands, Endocr. Jap., 8: 205-209.

6. A tk in son, W. B., W ils o n, F., Coat es, S. \& R o s c o e, B., 1959: The nature of the sexual dimorphism of the submandibular gland of the mouse. Endocr., 65: $114-117$.

7. [В а bаjeva, A. G. \& Burgilova, R. S.] Бабаева, А. Г. \& БургилоВ а, Р. С., 1961: Структура регенерирующей слюнной железы крыс. Бюль. Эксп. Биол. Мед., 51: 92.

8. B a rański, S. \& S a w i cki, W., 1960: Badania nad wbudowywaniem siẹ $\mathrm{P}^{32}$ - fosforanu i $\mathrm{S}^{35}$ - siarczanu do zawiązków kończyn kurczęcia. Folia morphol., 9: 41-48. Warszawa.

9. B a rgman n, W., 1939: Die Epithelkörperchen. [M ölle nd or f: Hdb. d. mikros. Anat. d. Menschen], Berlin, Springer J., 6: 137.

10. B argmann, W., 1955: Die Funktionelle Morphologie der Hormonbildungsstätten. Klin. Wschr., 33: $322-328$.

11. Be ns ley, S. H., 1947: The normal mode of secretion in the parathyroid gland of the dog. Anat. Rec., 98, 3: 361-381.

12. Bixler, D., Muhler, J. C., Webster, R. C. \& Shafer, W. G., 1957: Changes in submaxillary gland ribonucleic acid following hypophysectomy, thyroidectomy and various hormone treatments. Proc. Soc. Exp. Biol. Med., 94: $521-526$.

13. B i xler, D., MI uhler, J. C. \& Sh af er, W. G., 1959: Growth hormone and tyroxine: effect on submaxillary gland of hypophysectomized rat. Proc. Soc. exp. Biol., 100, 2: 400-402.

14. B o beau, G., 1911: Recherches cytologiques sur les glandules parathyroïdes du cheval. J. Anat. Physiol., 47: 371.

15. Boyd, G. A., 1955: Autoradiography in biology and medicine. New York.

16. Brachet, J., 1957: Biochemical cytology. Acad. Press., New York: 228-286.

17. B u d g e s, J., 1928: Handbuch der inneren Sekretion., 2: 215-220.

18. C a s pers s o n, T., 1950: Cell growth and cell function. Norton Co., New York.

19. Castleman, B. \& M allory, T. B., 1935: The pathology of the parathyroid glands in hyperparathyroidism. Am. J. Path. 11: 1-72.

20. Ch a r vá t, J., 1954: Prístítná telíska. Thomayerowa Sbírka (Praha): 1-77.

21. Com a r, C. L., 1958: Izotopy promieniotwórcze w biologii i rolnictwie. Państw. Wyd. Nauk.: 1-493. Warszawa.

22. Correi a M a deir a, A., 1942: Sur certaines particularités de la cytologie des glandes parathyroïdes chez quelques mammifères. Arch. Port. Sc. Biol., ó: $246-254$.

23. Coreia Madeira, A., 1945: Glandulas paratiroideias dos mammíferos (Estudo citologico). 1-149. Lisboa.

24. Correia M a deir a, A., 1946: Les cellules claires de la parathyroïde. Arch. Port. Sc. Biol., 8: 51-57.

25. Courvier, R. \& Reiss, P., 1922: Appareil réticulé de Golgi et polarité sécretoire des cellules parathyroïdiennes. C. R. Soc. Biol. (Paris), 86: 867-863

26. Czerski, P., 1952: Z badań nad cytologią przytarczyc. Folia morphol., 3: 407414. Warszawa. 
27. C z e r ski, P., 1952: Obecny stan wiedzy histofizjologii przytarczyc ssaków. Pol. Tyg. lek., 7: 1-18.

28. De ch a ume, M., 1958: Endocrinologie des glandes salivares. La Presse Medicale (Paris)., 66: 584-586.

29. Dewe y, M., 1958: A histochemical and biochemical study of the parotid gland in normal and hypophysectomised rats. Am. J. Anat., 102, 2: 243-271.

30. Di as - A m a d o, L. E \& Correi a M a d e ir a, A., 1944: Les éléments argentophiles de la parathyroïde. Arch. Port. Sc. Biol., 7: 190--196.

31. Dzierźykray-Rogalska, I., 1954: Die Veränderlichkeit der Parachyreoidea des Sorex araneus L. in seinem Lebenszyklus Ann. Univ. M. Curie-Skłodowska, C 9: 139-162. Lublin.

32. Dzi erży kray-R og a lska, I., 1958: Badania doświadczalne nad przytarczycą szczura białego. Folia morphol., 335-339. Warszawa.

33. Dzierźykray-Koga lska, I., Chodynicki, St. \& Wiśnie wski, L., 1960: Wplyw usunięcia jąder na śliniankẹ przyuszną i gruczoł Loeventhala myszy białej. Endokr. pol., 11: 105-116.

34. Dzierżkray-Rogalska, I., \& Gutsze, L., 1963: Wplyw parotyny i usunięcia ślinianek przyusznych na obraz autoradiograficzny kości szczurów białych. Endokr. pol., 14: 11-18.

35. Ede r, M. \& H a r t 1, F., 1955: Zur funktionellen Morphologie der Epithelkörperchen. Beiträge zur pathologischen Anatomie und zur allgemeinen Pathologie. Beitr. path. Anat., 115: 470-487.

36. Ed e r, M., 1961a: Morphological studies of focal hyperplasia in the parathyroid glands. Virchows Arch. Path. Path. Anat., 334, 4: 301-323. [In Germain].

37. E d e r, Ni., 1961b: Experimental and histochemical studies of focal hyperplasia in the parathyroid glands. Virchows Arch. Path. Anat., 334, 4: 324-336. [In German].

38. E g e r, W., 1954: Die Stellung der Epithelkörperchen im innersekretorischen System. Deutsche med. Wschr., 79: 1425-1430.

39. Elk in to n, J. R. \& D a n ow s k i, T. S., 1955: The body fluids. Basic physiology and practical therapeutics. W. Wilkins Co., Baltimore.

40. Englis h, J. A., 1960: Effects of radiation upon the salivary glands. Ann. New York Acad. Sc., 85: 342-348.

41. F a r ris, E. J. \& Griffith, J. Q., 1949: The rat in laboratory investigation. J. B. Lippincott Co., London: 1-542.

42. Federer, W. T., 1955: Experimental design. The Macmillan Co., New York, 97.

43. F is her, R. A., 1957: Statistical tables. Oliver nad Boyd, London: $44-51$.

44. Fleming, H. S., 1960: The effect of parotin in mice. Ann. New York Acad. Sc., 85: $313-323$.

45. Forster, C. L., 1943a: The cytology of the normal gland in relation to its secretory activity. J. Endocr., 3: 244-253.

46. Forster, C. L., 1943b: Studies on the parathyroid of the mouse. J. Endocr., London., 3:

47. Forster, C. L., 1946: Studies on the parathyroid of the mouse. J. Anat., 80:

48. Fortina, A., 1948: Contributio allo studio delle paratiroidi nel rachitismo sperimentale del ratte. Riv. Anat. Patol. Oncol., Parma, 1: 226-280. 
49. Fuji i, A., Kom ura, M. \& Y ang, M. F., 1960: The effects of adrenalectomy and cortisone upon the glycogen contents in various organs especially in the parathyroid gland of the rat. Acta Scholae Med. in Gifu., 8: 600-612.

50. Fu ji i, A., 1960: Histochemical studies on the parathyroid gland of the rat in various pre- and postnatal stages. Acta Scholae Med. in Gifu. 8: 693-711.

51. Fujki, S., Nishioka, M., M ukudai, Y. \& W ada, H., 1960: Studies on the action of saliva. III. Effects of the extirpation of the salivary glands on the secretory activity of the gastric peptic cells. Arch. Histol. Jap., 18, 4: 565-5?2.

52. G a be, M. M., 1950: Action du rachisme sur la glande sousmaxillaire de la souris albinos. C. R. Acad. Sc., 230: 72-74.

53. G e tzow a, S., 1907: Über die Glandula parathyreoidea, intrathyreoideale Zellhaufen derselben und Reste des postbranchialen Körpers. Virchows Arch., 188. 181.

54. Go de t, R., 1956: Sur le déterminisme hormonal de l'évolution cyclique de la glande salivaire parotide chez la Taupe mâle. C. R. Acad. Sc. 242: 2037-2039.

55. Godlowski, Z. Z. \& Cal andra, J. C., 1960: Salivary glands as endocrire organs. J. Appl. Physiol., 15, 1: 101-105.

56. Goudal, H., 1955: Les variations du nombre des parathyroïdes chez le rat blanc. Ann. Endocr. (Paris), 16, 2: 227-228.

57. Godlewski, H. \& Vorbrodt, A., 1954: Przystosowanie metody Bracheta do histochemicznego wykrywania kwasów nukleinowych. Folia morphol, 5: 137.

58. G r a u, H. \& D ell m a n n, H. D., 1958: Uber tierartliche Unterschiede der Epithelkörperchen unserer Haussäugertiere. Z. mikr.-anat. For., 64: 192-214.

59. Grandos, H., 1951: Nutritional studies on growth and reproduction of the golden hamster. Acta physiol. Scand., 87, 24 Suppl.: 69-97.

60. Grauman n, W. \& Cla u s, W., 1958: Weitere Untersuchungen zur Spezifität der histochemischen Polysaccharid-Eisenreaktion. Acta histochem. 6: 1-7.

61. Hadler, W. A., Corrado, A. P. \& M igliorini, R. H., 1962: Analyse de l'activité fonctionnelle des parathyroides, chez le rat, par la caryométrie et l'histométrie. Z. mikr.-anat. Forsch., 68: 507-512.

62. H a mper l, H., 1950: Oncocytes and the so-called Hürthle cell tumor. Arch. Path., 49: 563-567.

63. H a n s s le r, H., 1953: Experimentelle Untersuchungen über die Beziehungen der Nebenschilddrüsenmorphologie und Funktion zur Vitamin D-Wirkung. Ztschr. Ges. Exper. Med., 121: 209-227.

64. H a r a, S., K a to, H. \& I s on o, S., 1957: The effects of adrenalectomy upcn the glycogen stores in various organs, especially of the parathyroid gland. Acta Scholae Med. in Gifu., 5: 175-199.

65. Har a, S., Furuta, T., Murata, Y. \& Yang, M. F., 1959: Relating to the changes of the glycogen contents in the parathyroid gland of the hamster during the various developmental stages. Acta Scholae Med. in Gifu, 7: 107-116.

66. H a ra, S. \& Y a m a d a, K., 1962: Some features of the structure and histochemistry of the rat parathyroid gland. Z. Zellforsch. mikr. Anat., 57: 360-370.

67. H a r twig, W., 1962: Najważniejsze testy diagnostyczne w chorobach przytarczyc i tarczycy. Wiad. lek. 15: 181-190.

68. H a r ve y, H., 1952: Sexual dimorphism of submaxillary glands in mice in relation to reproductive maturity and sex hormones. Physiol. Zoöl., 25: 205-221.

69. [I g n a ti e va, Е. Р.] И гнатьев а, Е. П., 1948: Морфологические критерии функционального состояния паращитовидных желез млекопитающих животных. Изв. АН СССР, 5: 587. 
70. In $n$ e s, J. R. M. \& S t a n t 0 n, MI. F., 1961: Acute disease of the submaxillary and harderian glands (sialo-dacryoadenitis) of rats with cytomegaly and no inclusion bodies. Am. J. Path., 38: 45j-468.

71. I t o, Y., 1954: Biochemical studies on salivary gland hormone. Endocr. Jap., 1: $1-50$.

72. It o, Y. \& Ok a be, S., 1955: On the occurrence of a parotin-like substance (saliva-parotin) in the human saliva. Endocr. Jap., 2: 195.

73. I to, Y. \& Endo, H., 1956: Studies on the salivary gland hormones in tissue culture. I. The effects of parotin on the longitudinal growth and calcium deposition of chick embryo femora in vitro. Endocr. Jap., 3: 108-115.

74. I t o, Y., 1960: Parotin a salivary gland hormone. Ann. New York Acad. Sc., 85: $228-310$.

75. K a w a d a, J., 1962: On the functional correlation between salivary glands and other endocrine organs. V. Changes in rat salivary glands following thyroidectomy, administration of anti-thyroid drugs and thyroxine-treatment. Endocr. Jap., 8: 259-271.

76. Krach t, J., 1960: Atrophy of the salivary glands caused by parotin. Speicheldrüsenatrophie durch Parotin. Z. Path., Frankfurt, 70, 5: 507-512.

77. K rook, L., 1957: Spontaneous hyperparathyroidism in the dog. Acta Path. Microbiol Scand. (Copenhagen), 41, 122 Suppl.: 1-88.

78. Krygier: A., 1940: Badania cytochemiczne i cytofotometryczne fibroblastow w hodowli tkanek. Soc. Sci. Stetinensis., 6: 5-42.

79. L a c as s a n e, A., 1940: Dimorphisme sexuel de la glande sous-maxillairc chez la souris. C. R. Soc. Biol., 133: 180-181.

80. Lange, R., 1961: Zur Histologie und Zytologie der Glandula parathyreoidea des Menschen. Licht- und elektronenmikroskopische Untersuchungen an Fpithelkörperadenomen. Z. Zellforsch., 53: 765-828.

81. L e e s o n, C. R., 1960: The histochemical identification of myocpithelium, with particular reference to the harderian and exorbital lacrimal glands. Acta anat., 40: 87-94.

32. Lever, J. D., 1958: Cytological appearances in the normal and activated parathyroid of the rat. A combined study by electron and light microscopy with certain quantitative assessments. J. Endocr., 17: 210-218.

83. Levi-M ontalcini, R. \& Cohen, St., 1960: Effects of the extracts of the mouse submaxillary salivary glands on the sympathetic system of mammals. Ann. New York Acad. Sc., 85: 324-341.

84. L i c h t wit $\mathrm{z}$, A. \& $\mathrm{Clément,} \mathrm{D.,} \mathrm{1955:} \mathrm{Les} \mathrm{régulations} \mathrm{hormonales} \mathrm{du} \mathrm{méta-}$ bolisme calcique. La Semaine des Hôpitaux, 31: 206-215.

85. M c M a n us, J. F. A., 1948: The periodic acid routine applied to the kidney. Amer. J. Path., 24: 643-653.

86. M i n a m i, A. \& K a m e i, T., 1959: Sur la glande lacrimale extérieure chez le rat et ses modifications aprés hypophysectomie. C. R. Soc. Biol., 153: 269-271.

87. Morga n, J. R. E., 1936: The parathyroid glands. Arch. Path., 21: 10-26.

88. M y a n t, N. B., 1960: Iodine metabolism of salivary glands. Ann. New York Acad. Sc., 85: 203-214.

89. O gata, T., 1955: The internal secretion of salivary gland. Endocr. Jap., 11: $1-15$.

90. Oleki ewicz, M.: 1956: Statystyka jako metoda poznawcza. Zeszyty proble mowe „Kosmosu”, 2: 102-235. Warszawa. 
91. Ostrowski, K., 1957: Mikroautoradiografia. Metody, zastosowanie i wyniki. Folia morphol., 8, 16: 128.

92. Parhon, C. I., B abes, A., Petrea, I. \& Burgher, E., 1955a: Testiculul la sobolanii albi parotidectomizati uni si bilateral. Studii si cercetari de Fndocr., $6,3-4$.

93. P a r hon, C. I., B a bes, A., P e trea, I. \& Is trat i, F., 1955b: Asupra structuri glardelor parotide de sobolan in raport cu virsta si momentul aparitiei dimofismului sexual. Comunicare Academiei R. P. R., 5: 12, 1-310.

94. Parhon, I. C., Petrea, I. \& S a posnic, Al., 1956: Asupra actiunii hiperglicemiante a unui extract de parotida. Studii si cercetari de Endocr., 7: 2.

95. Parhon, I. C., B a bes, A. \& P e tre a, I., 1957: Endocrinologia glandelar salivary. Academia Republicii Populare Romine. Biblioteca Medicale, 5: 1-200.

96. Pe arse, A. G. E., 1957: Histochemia teoretyczna i stosowana. Państw. Zaikł. Wyd. Lek.: 1-535. Warszawa.

97. Pe arse, A. G. E. \& $\mathrm{Tremblay}, \mathrm{G}$., 1958: Leucine aminopeptidase in rat parathyroid and its relation to parathyroid hormon production. Nature, 181: 1532-1533. London.

98. P i c a r d, J., 1955: Action de la parathormone dans le métabolisme phospho-calcique. La Presse Medicale, 63: 1320-1324.

99. R a u c h, S., 1959: Die Speicheldrüsen des Menschen. G. Thieme - Stuttgart.

100. R a y $\mathrm{n}$ a $\mathrm{u}$, J., 1954a: Nouvelles observations concentrant les transformations aprés castration, de la glande sous-maxillaire de la souris mâle. C. R. Soc. Biol., 148: $1743-1747$.

101. R a y $\mathrm{n}$ a u d, J., 1954b: Effects de la surrénalectomie, associée à la castration sur la structure de la glande sous-maxillaire de la souris mâle. C. R. Soc. Biol., 148: $1939-1942$.

102. Robertis de, E. D. P., 1940: The cytology of the parathyroid glard of rats injected with parathyroid extract. Anat. Rec., 78: 473-495.

103. Robertis de, E. D. P., 1941: The cytology of the parathyroid and thyroid glands of rats with experimental rickets. Anat. Rec., 79: 417.

104. R obertis de, E. D. P., Nowi ński, W. W. \& S a e z, F. A., 1949: General Cytology. 1-456. Philadelphia.

105. R o m e is. B.. 1948: Mikroskodische Technik. München. 1-530.

106. R os of, J. A.: 1934: An experimental study of the histology and cytology of the parathyroid glands in the albino rat. J. exp. Zoöl., 68: 121-165.

107. R u c a r t, G., 1949: Classification et valleur fonctionnelle des cellules parathyrö̈diennes des mammifères. Arch. Anat. Micr. Morph. Expér., 38: 1.

108. S a n d s trö m, J., 1880 (acc. to Krook, 1957): Uppsala Läk Fören. Förn., 15: 441.

109. Sannazzari, P., Belloni, L. \& Menozzi, P. G., 1959: Histomorphological modification of parathyroids following administration of PTH. Arch. E. Maragliano Pat. Clin., 15, 5: 1499-1504.

110. Sassaki, T., Nakajima, H., Kanda, K., Ariyoschi, T. \& Mochi$\mathrm{zuki}, \mathrm{H} ., 1953$ : Treatment of chondrodystrophia foetalis and refractory rickets with parotin. Acta Paediatrica Jap., 57: 584.

111. S a wicki, W., 1960: O wewnętrznym wydzielaniu ślinianek. Wiad. lek., 1.3: $797-805$.

112. S a w i cki, W., 1961: Tracer studies on the functional relation between salivary glands and the thyroid. Bull. Acad. Pol. Sci., cl. II, 9: 337-339.

113. Schneider, R. M. \& Pers on, P., 1960: Aerobic oxidative metabolism of salivary glands. Ann. New York Acad. Sc., 85: 201-207. 
114. Schneyer, L. H. \& S chneyer, Ch. A., 1960: Regulation of salivary gland amylase activity. Ann. New York Acad. Sc., 85: 189-200.

115. Sh a fer, W. G. \& M uhler, J. C., 1960: Endocrine influences upon the salivary glands. Ann. New York Acad. Sc., 85: 215-227.

116. Shibata, K., Neg ishi, A., S a ito, K. \& T adokoro, S., 1954: Effect of salivary gland-ectomy on the response of the tibial epiphysis ot growth hormone. Endocr. Jap., 1: 203-207.

117. Sne 11, G. D., 1956: Biology of laboratory mouse. Dover publication Inc.: 1-New York.

118. Soszka, S. \& Krawczuk, A., 1960a: O wpływie niektórych ezynników na obraz morfologiczny jądra szczura białego. Uszkodzenie ślinianki przyusznej. Ginek. pol., 31: 501-508.

119. Soszka, S. \& Krawczuk, A., 1960b: Wpływ uszkodzenia ślinianki przyusznej na obraz morfologiczny jajników szczura bialego. Pam. XIV Zjazdu Ginekologów. Państw. Zakł. Wyd. Lek., 775-786. Krynica.

120. Sreebny, L. M., 1960: Studies of salivary gland proteases. Ann. New Yorl: Acad. Sc., 85: 182--188.

121. Takiz a wa, N., 1954: A pathological research on the internal secretion of the salivary glands. Acta Path. Jap., 4: 129-166.

122. T a $1 \mathrm{mage}$, R. V. \& Dodds, B. F., 1955: Comparative study of some effects of administration of dihydrotachysterol and calciferol to rats. Endocr., 57: 236.

123. Tremblay, G. \& Pear s e, A. G. E., 1959: A cytochemical study of oxydative enzymes in the parathyroid oxyphil cell and their functional significance. Brit. J. exptl. Path., 40: 66-69.

124. W a lker, R., 1958: Age changes in the rat's exorbital lacrimal gland. Anat. Rec., 132: 49-69.

125. W a $1 \mathrm{th}$ a $\mathrm{rd}, \mathrm{B}$, 1961: Electron-microscopical study of the parathyroids. Arch. De Vecchi Anat. Path. Univ. Bern. (Exc. Med. Sec. I, 15: 500).

126. Wels c h, R., 1898: Concerning the parathyroid glands. J. Anat. Physiol.

127. Weymouth, R. J., 1957: The cytology of the parathyroid glands of the rat after bilateral nephrectomy, administration of parathyroid hormone and hypophysectomy. Anat. Rec., 127: 509-525.

128. W iśni e wski, L., 1960: O wpływie trzebienia na obraz morfologiczny przedniego płata przysadki mózgowej, gruczołu tarczowego, przytarczyc oraz nadnerczy myszek białych. Endokr. pol., 11: 299-312.

129. V a ler i, V. M., 1954a: Nuclear volume and testosterone-induced changes in secretory activity in the submaxillary gland of mice. Science, 120: 984-985.

130. V a le ri, V. M., 1954b: Action de la testostérone sur le volume nucléaire dans la glande sous-maxillaires de la souris. Comp. Rend. S. Acad. Sc., 238: 16131615.

131. Y a n g, M. F., 1960: On the changes of histological structure, especially glycogen contents of the parathyroid gland of the white rat during pregnancy and puerperium. Acta Scholae Med. in Gifu, 8.

132. Z a w is t o w s k i, St., 1962: Cytochemická studie o nekterých enzymech v parathyreoidei krysy za ruzných pokusných stavu. Ceskoslov. Morfol., 10: 205-212.

Medical School,

Dept. of Histology,

Białystok, Kilińskiego 1. 


\section{STRESZCZENIE}

Autorka zajmuje się zależnością między przytarczycami a śliniankami przyusznymi - gruczolami związanymi z gospodarką fosforowo-wapniową organizmu. W tym celu przebadała:

1. Wpływ usunięcia przytarczyc na obraz morfologiczny ślinianek przyusznych.

2. Wpływ usunięcia ślinianek przyusznych na obraz morfologiczny przytarczyc.

3. Wpływ podawania parotyny na obraz morfologiczny przytarczyc i ślinianek przyusznych.

4. Wpływ usunięcia ślinianek oraz podawania parotyny na kości szczurów. Badania przeprowadzono przy użyciu $\mathrm{P}^{3 \mathbf{3}}$.

5. Dodatkowo przeprowadzono analize statystyczną opracowanego materialu.

Po usunięciu przytarczyc w śliniance przyusznej szczura występuje zanik tkanki gruczołowej na rzecz tkanki tłuszczowej, co może świadczyć o wycofywaniu się pewnych partii miąższu gruczołowego z czynności.

W wyniku usunięcia ślinianek otrzymano w przytarczycach następujące zmiany: powiększenie się wymiarów komórek gruczołowych i ich jąder, obecność licznych podziałów komórkowych, stałe ułożenie jąderka w pobliżu błony jądrowej oraz zwiększanie się ilości komórek jasnych - czynnych. Powyższe dane pozwalają na wyciągnięcie wniosku, że przytarczyce po usunięciu ślinianek wykazują cechy pobudzenia.

Po przeprowadzeniu doświadczeń polegających na podawaniu parotyny uzyskano: zmniejszenie się jąder komórkowych, zmniejszenie się pironino-chłonności protoplazmy, powiększenie się ilości tkanki łącznej w przytarczycach oraz zmniejszenie się komórek i jąder komórkowych w pęcherzykach śliniankowych.

Obserwacje te świadczą o osłabionej czynności zarówno przytarczyc jak i ślinianek u szczurów traktowanych parotyną.

Do badań autoradiograficznych użyto szczury z wyciętymi śliniankam! oraz szczury, którym podawano parotynę. Przy użyciu radioaktywnego $\mathrm{P}^{32}$ badano wpływ powyższych czynników na poziom fosforu w kościach szczurów. Największą aktywncść $\mathrm{w}$ popiele kostnym uzyskano u zwierząt, które otrzymywały $0,2 \mathrm{mg}$ parotyny na $100 \mathrm{~g}$ wagi ciała w ciągu tygodnia. Wynikom tym odpowiada obraz autoradiograficzny. Najmniejszą ilość impulsów stwierdzono w popiele kostnym zwierząt, które zostały sekcjonowane $w$ tydzień po usunięciu ślinianek, czemu odpowiada obraz autoradiograficzny.

Przeprowadzona analiza statystyczna opracowanego materiału umożliwiła stwierdzenie, że: a) w przytarczycach zwierząt $z$ usuniętymi śliniankami występują większe jądra komórkowe w porównaniu ze zwierzętami kontrolnymi, b) pod wplywem parotyny $w$ przytarczycach zwierząt nie spotyka się jąder zarówno bardzo dużych jak i bardzo małych. Wydaje się, że parotyna działa na ujednolicenie przeciętnych rozmiarów jąder.

Jak wynika z powyższych danych, usunięcie przytarczyc spowodowało zmiany morfologiczne $w$ śliniankach przyusznych świadczące o wycofaniu się tych gruczolów z czynności.

$\mathrm{Z}$ drugiej strony usunięcie ślinianek, wywołało nadczynność przytarczyc, a podawanie parotyny spowodowało zablokowanie czynności przytarczyc.

Wydaje się, że powyższe wyniki wskazują na istnienie działania zwrotnego cbu gruczołów z tym, że przytarczyczki są gruczołem nadrzẹdnym (produktorem) w stosunku do ślinianki przyusznej (efektora).

$Z$ przeprowadzonych doświadczeń wynika również, że ślinianki wywierają swójj wpływ nie tylko na przytarczyce, ale również na tkankę kostną. Usunięcie ślinianek 
przyusznych powoduje bowiem charakterystyczne obniżenie się poziomu $\mathrm{P}^{32} \mathrm{w}$ kosci, podczas gdy podawanie parotyny wplywa na wzrost zawartości $P^{3:}$. W oparciu o otrzymane wyniki autorka wysuwa dwie hipotezy, dotyczące wpływu slinianek na kość. Według pierwszej z nich ślinianka przyuszna wpływa bezpośrednio na tkank kostną, wedlug drugiej - poprzez gruczoły przytarczycowe, które jak wiadomo dotychczas wpływają decydująco na przemianę fosforowo-wapniową.

\section{EXPLANATION OF PLATES}

\section{Plate X.}

Fig. 1. Parotid salivary gland. Control. Large amount of RNA in the basic parts of the vesicular cells. Magnified 450 $\times$.

Fig. 2. Striated duct. Control. Striation in the basic parts of the cells. Magn. 1160 K.

Fig. 3. Parotid salivary gland (after removal of parathyroid gland). Interlobular duct. The inner layer of the epithelium flakes of into the lumen of the duct. Magn. $150 \times$.

Fig. 4. Parotid salivary gland (after removal of parathyroid gland). In addition to normally formed lobes, there are lobes of altered structure. Magn. 150 $\times$.

\section{Plate XI.}

Fig. 5. Parotid gland (after removal of the parathyroid gland). The vesicles have a large lumen slightly similar to the vescles iof the thyroid gland. Lumen of vesicles filled with secretion. Magn. $450 \times$.

Fig. 6. Parotid salivary gland (after removal of the parathyroid gland). In the altered lobe (right) the cytoplasm of the cells exhibits intensive vacuolisation. Magn. $300 \times$.

Fig. 7. Parotid salivary gland (after removal of the parathyroid gland). Connective tissue with a large number of fatty cells penetrates between the altered vesicles. Magn. $150 \times$.

Fig. 8. Parotid salivary gland (after removal of the parathyroid gland). Continued process of penetration by the connective tissue with simultaneous atrorhy of the glandular vesicles. Magn. $150 \times$.

Fig. 9. Parotid salivary gland (after removal of the parathyroid gland). Lobes of connective tissue have been formed in place of the glandular lobes, in them are the remaining striated ducts. Magn. $150 \times$.

\section{Plate XII.}

Fig. 10. Parathyroid glands of a control rat. The nuclei exhibit considerable polymorphism. Magn. $1160 \times$.

Fig. 11. Parathyroid gland after removal of the salivary glands. Light celis arranged in pseudo-vesicles with a small lumen in the centre. Cytoplasm filled with fine granular matter. Fixed by Lison-Voaker. Magn. $1160 \times$.

Fig. 12. Parathyroid gland (after removal of the salivary glands). Mitoses. Magn. $1160 \times$.

Fig. 13. Parathyroid gland (after removal of the salivary glands). PAS' granular matter in the cells lying in the periphery. Magn. $1160 \times$. 
Plate XIII.

Fig. 14. Parathyroid gland (after removal of the salivary glands). Large Golgi apparatus, formed of thick trabeculae, lying in the apical part of the cell. Magn. $2200 \times$.

Fig. 15. Parathyroid gland (after removal of the salivary glands). High cylindrical cells, situated with their base on blood vessels. Magn. $1160 \times$.

Fig. 16. Parathyroid gland (after removal of the salivary glands). Cells have acidiphilous cytoplasm and hyperchromatic nulei. Nuclei becoming narrower (bottom left). Magn. 1160X.

Fig. 17. Parathyroid gland (after removal of the salivary glands). The Golgi apparatus, situated on the apical pole of the cell, is formed of delicate single trabeculae and small fragments. Magn. 2200×.

\section{Plate XIV.}

Fig. 18. Parathyroid gland (after parotin injections). One kind of cell with dark cytoplasm and variform nuclei. Distinct reduction in dimensions of nuclei. (Peripheral part of gland). Magn. 1160X.

Fig. 19. Parathyroid gland (after parotin injections). The Golgi apparaus lying in the apical parts of the cells is small and scattered. Magn. $2200 \times$.

\section{Plate XV.}

Fig. 20. Parotid salivary gland (after parotin injections). Enlarged blood vessels and lymphatic vessels near the striated ducts. Magn. $450 \times$.

Fig. 21. Parotid salivary gland (after parotin injections). Enlarged blood vessels near the striated ducts. Magn. $450 \times$.

Fig. 22. Parotid salivary gland (after parotin injections). Reduction of RNA in the basic parts of the vesicles. Magn. $450 \times$.

Fig. 23. Parotid salivary gland (after parotin injections). PAS + granules visible in the intercalar ducts. Magn. $450 \times$.

\section{Plate XVI.}

Fig. 25. Autoradiogram of the base of a bone in a control rat.

Fig. 20. Autoradiogram of the base of a bone from a rat killed 7 days after excision of the salivary glands.

Fig. 27. Autoradiogram of the base of a bone from a rat killed 14 days after excision of the salivary glands.

Fig. 28. Autoradiogram of the base of a bone from a rat killed 21 days after excision of the salivary glands.

Fig. 29. Autoradiogram of the base of a bone from a rat which had been given $0.1 \mathrm{mg}$. parotin.

Fig. 30. Autoradiogram of the base of a bone from a rat which had been given $0.2 \mathrm{mg}$. parotin. 
PAŃSTWOWE WYDAWNICTWO NAUKOWE * WARSZAWA 1963 Nakład 1450 egz. Ark. wyd. 4,25. Maszynopis otrzymano 19.VII.1963. Podpisano do druku 2.XII.1963. Druk ukończono 10.XII. 1963. Papier druk sat. k1. III 80 g. Format B5. Cena $15 \mathrm{zl}$

Białostockje Zakłady Graficzne, Zam. 2780. * A-2. 

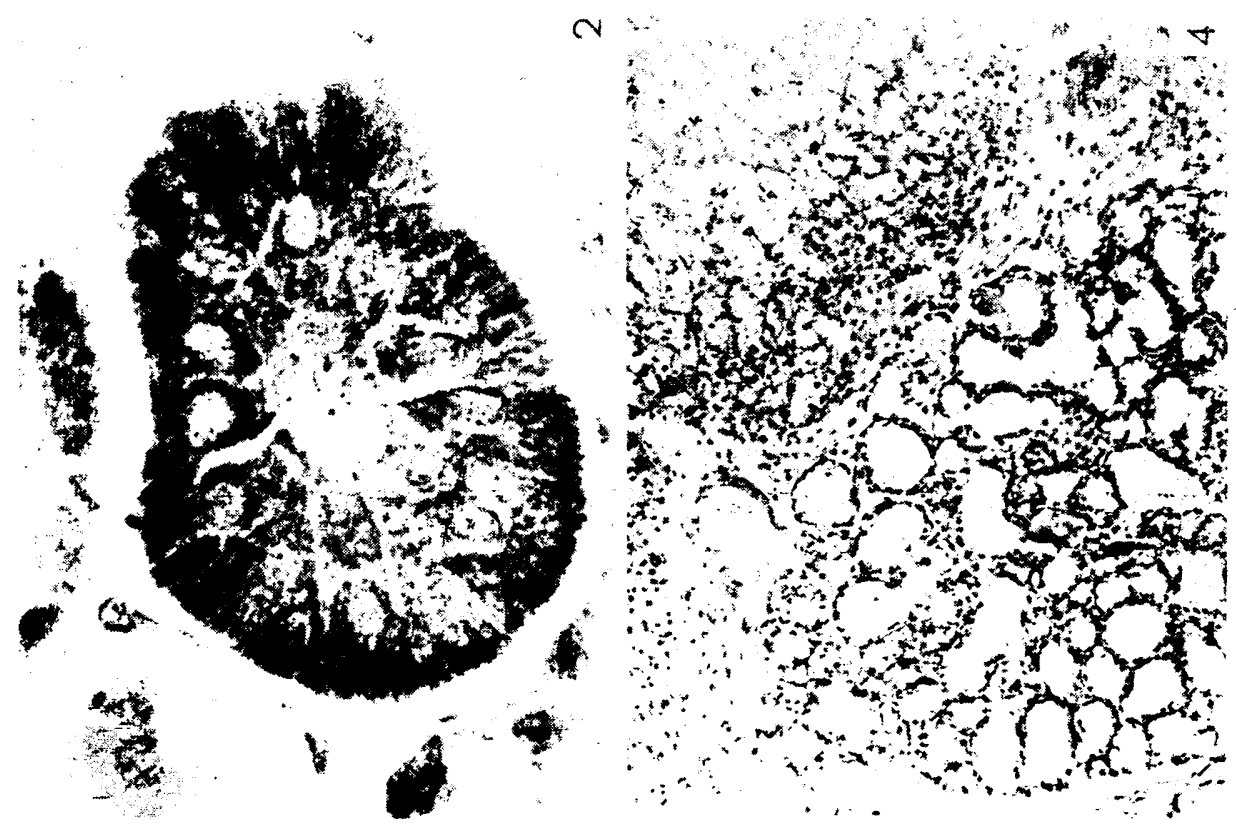

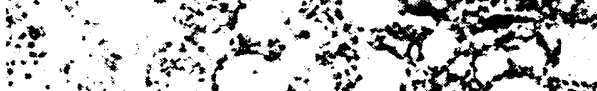
$\therefore$ ar $\therefore \quad \therefore$ and

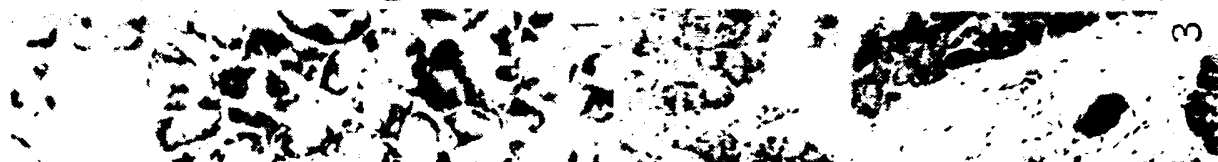

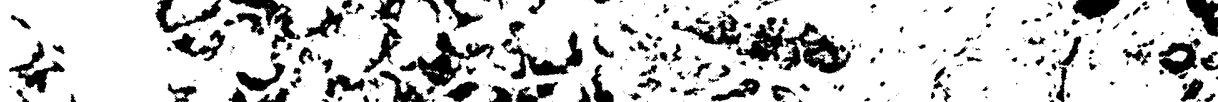

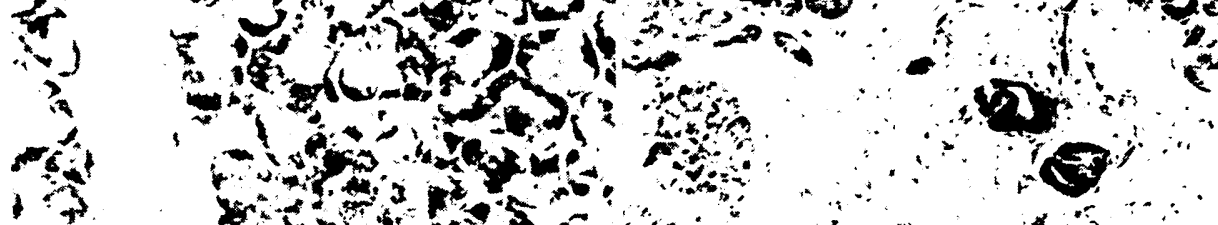

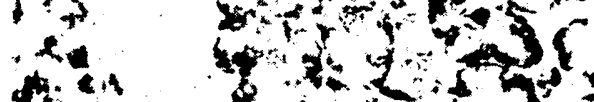
ing

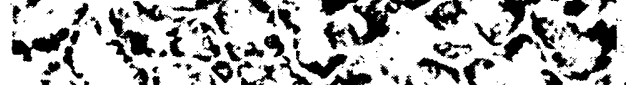

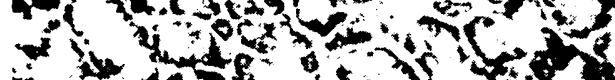

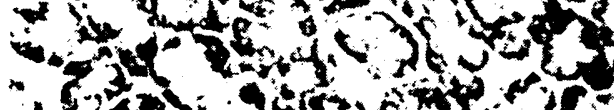

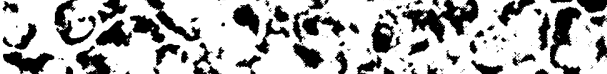

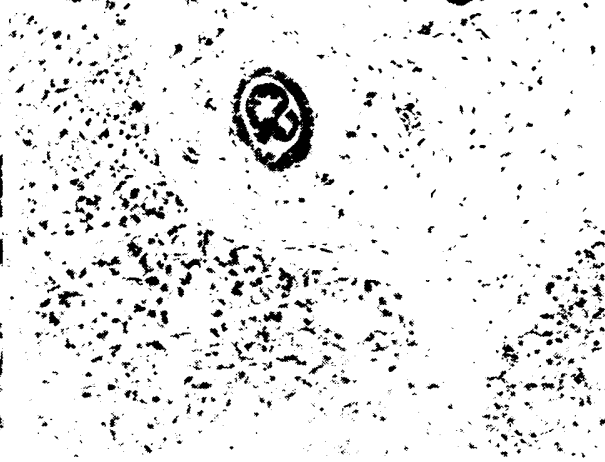



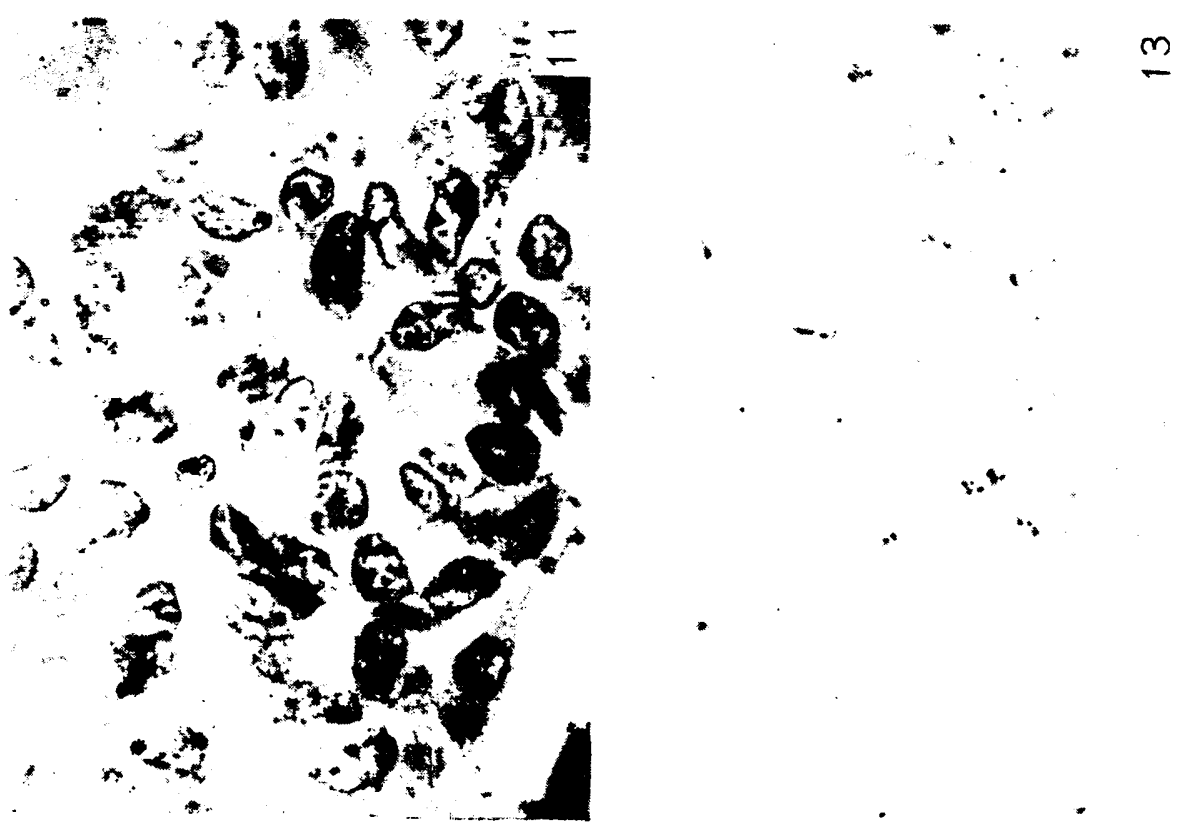

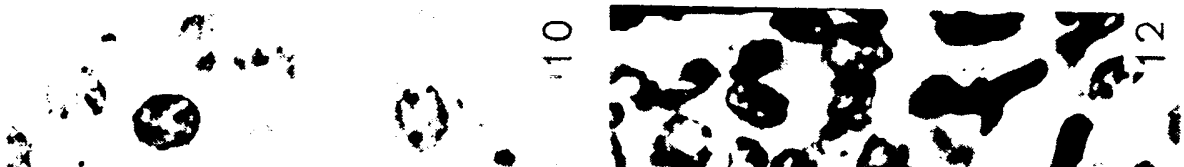

in s." -

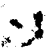

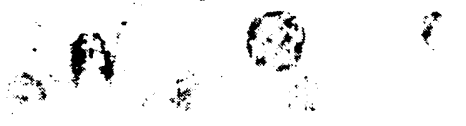
$3 \times 2$
$a^{2}$ 


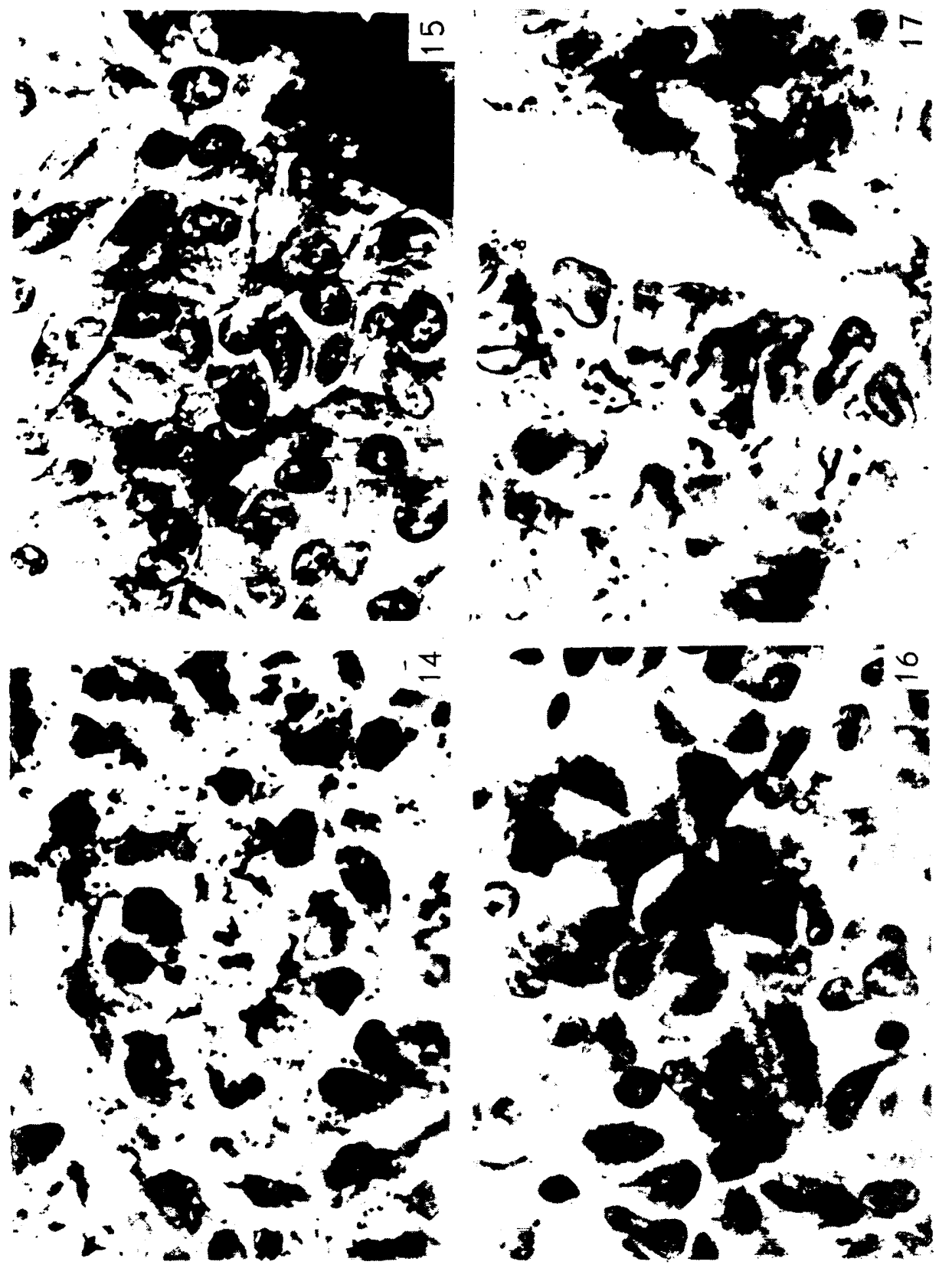



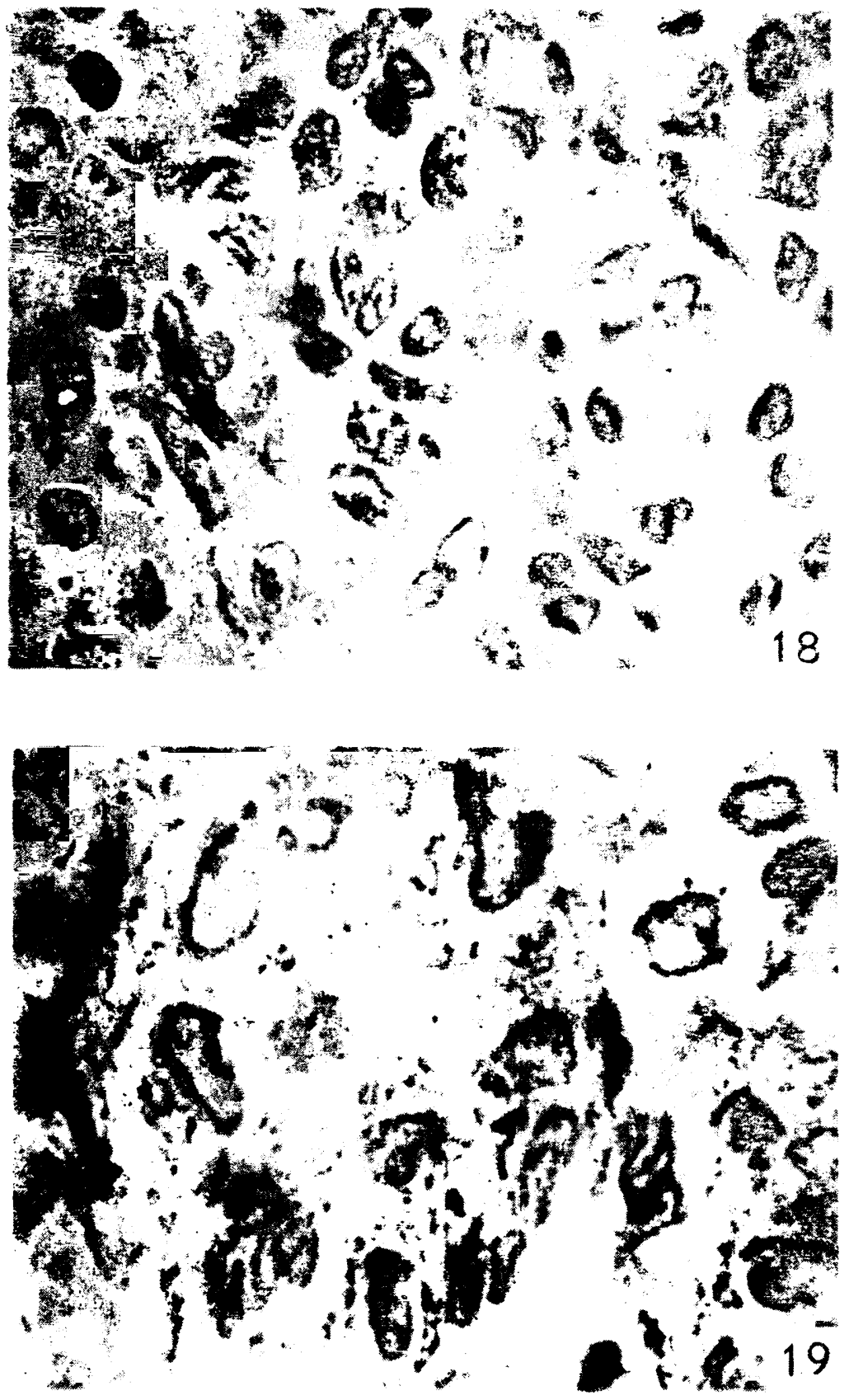

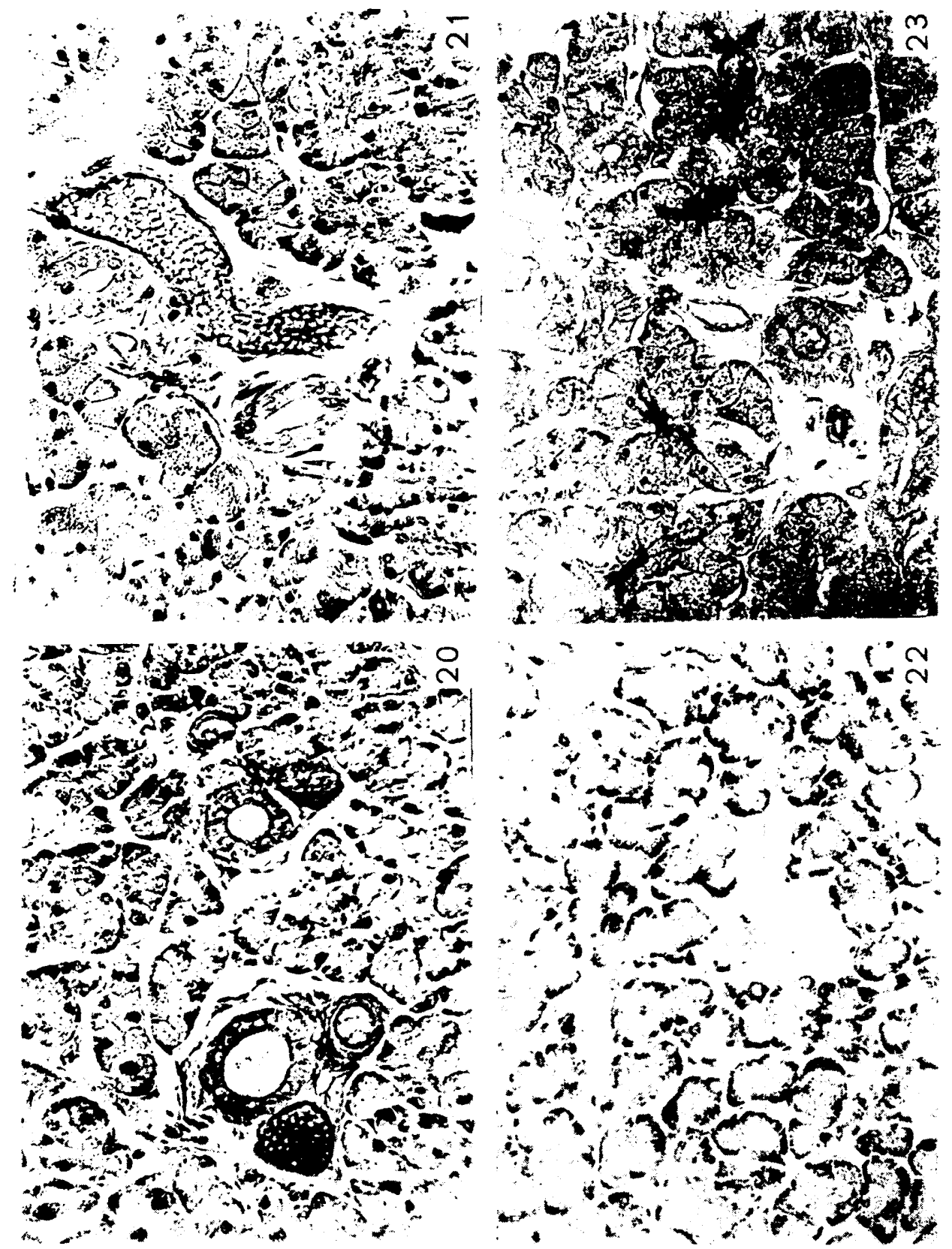

$+30+2$

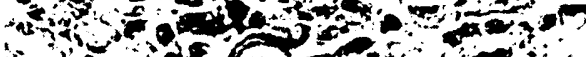

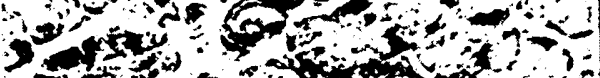

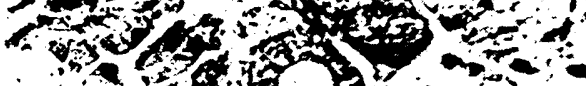

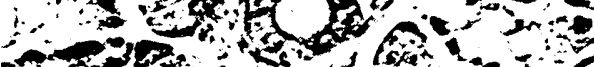
Py-2

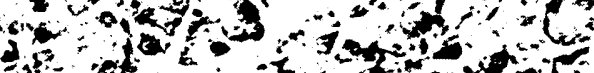

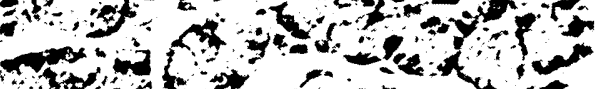
2

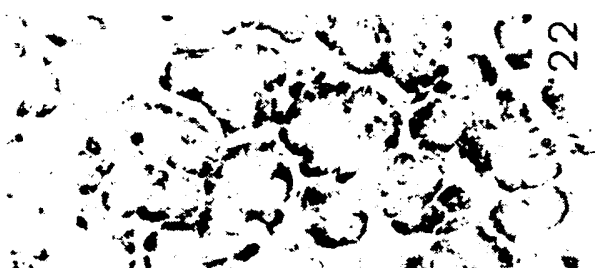

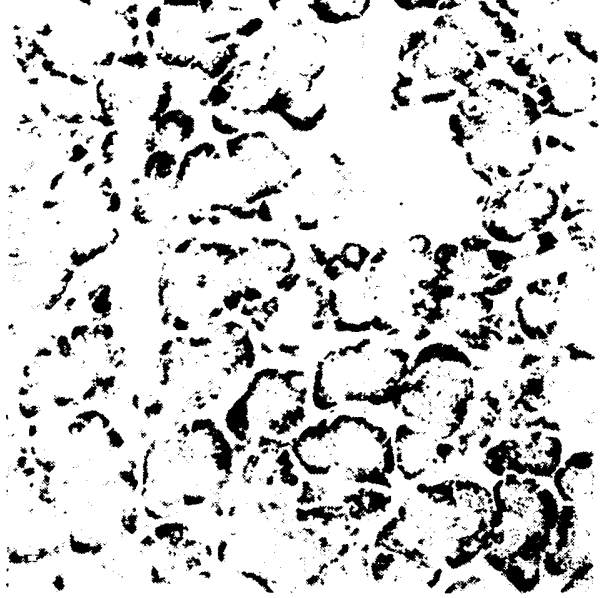




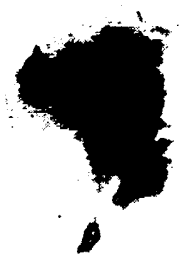

s.s.

$\rightarrow$
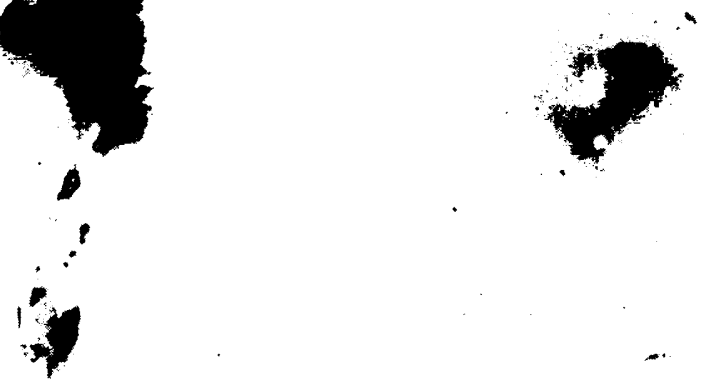

25
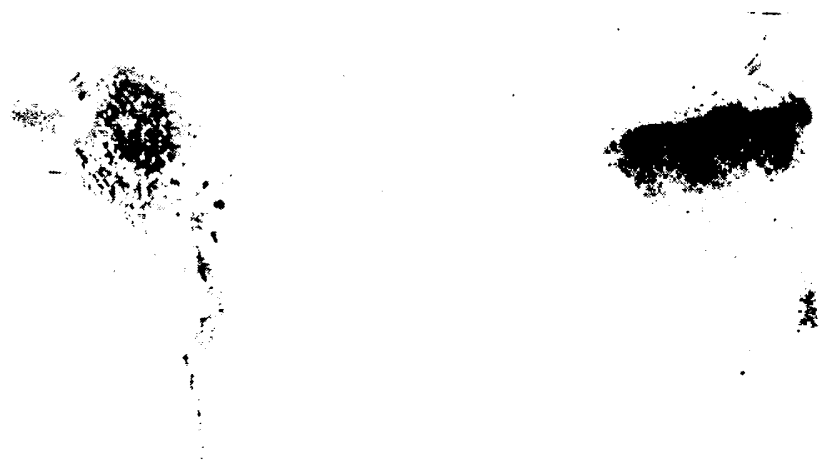

\$

27

28
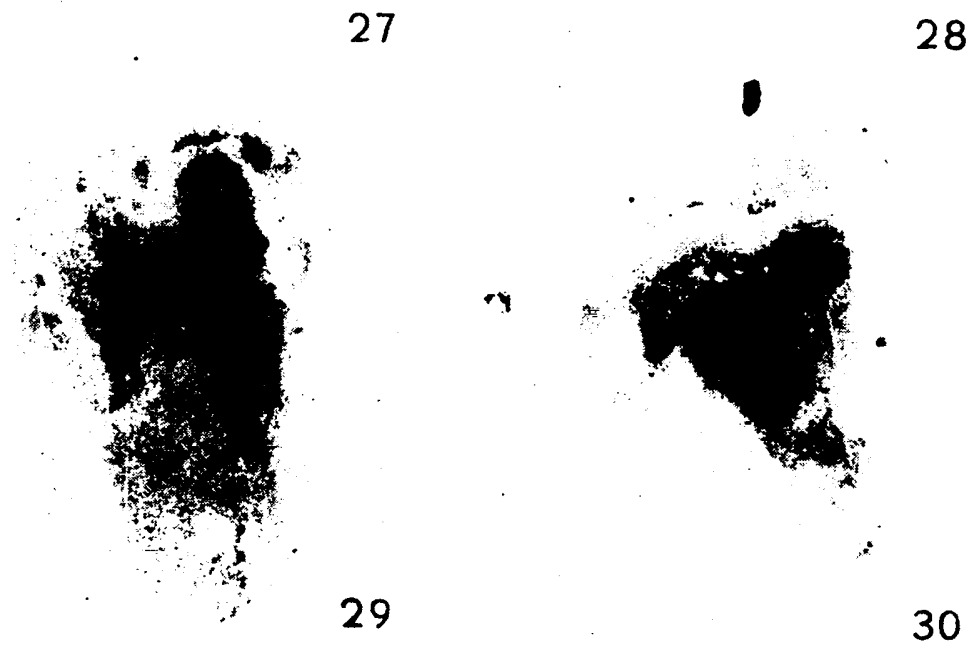

T. Dzierżykräy-Rogalska

auctor phot. 
BIBLIOTEKA

Instytutu Biologii Ssaków

Polskiej Akademii Nauk

Nr Cz. 40.2 